\title{
The Itombwe Massif, Democratic Republic of Congo: biological surveys and conservation, with an emphasis on Grauer's gorilla and birds endemic to the Albertine Rift
}

\author{
llambu Omari, John A. Hart, Thomas M. Butynski, N. R. Birhashirwa, Agenonga Upoki, Yuma \\ M'Keyo, Faustin Bengana, Mugunda Bashonga and Norbert Bagurubumwe
}

\begin{abstract}
In 1996, the first major biological surveys in the Itombwe Massif in over 30 years revealed that significant areas of natural habitat and remnant faunal populations remain, but that these are subject to ongoing degradation and over-exploitation. At least 10 areas of gorilla Gorilla gorilla graueri occurrence, including eight of 17 areas identified during the first survey of the species in the massif in 1959, were found. Seventy-nine gorilla nest sites were recorded and at least 860 gorillas were estimated to occupy the massif. Fifty-six species of mammals were recorded. Itombwe supports the highest representation, of any area, of bird species endemic to the Albertine Rift highlands. Twenty-two of these
\end{abstract}

species were recorded during the surveys, including the Congo bay owl Phodilus prigoginei, which was previously known from a single specimen collected in Itombwe nearly 50 years ago. No part of Itombwe is officially protected and conservation initiatives are needed urgently. Given the remoteness and continuing political instability of the region, conservation initiatives must collaborate with traditional authorities based in the massif, and should focus at the outset on protecting the gorillas and limiting further degradation of key areas.

Keywords Afromontane forests, Albertine Rift, Democratic Republic of Congo, endemic avifauna, gorillas.

\section{Introduction}

Since its earliest exploration in the first decade of this century by Emil Grauer (Matschie, 1914), the Itombwe Massif has been recognized as one of the most biologically distinctive regions in Africa. Itombwe, north-west of Lake Tanganyika in the Democratic Republic of Congo, is an area of forested mountains and high grassland plateaus covering about $6000 \mathrm{sq} \mathrm{km}$ (Fig. 1). Grauer's visits resulted in the collection of a number of

\footnotetext{
John A. Hart (corresponding author) Wildlife Conservation Society, International Programs, 185th St and Southern Boulevard, Bronx, NY 10460, USA. E-mail: 691.1261@mcimail.com
}

Thomas M. Butynski Zoo Atlanta's Africa Biodiversity Conservation Program, PO 24434, Nairobi, Kenya.

llambu Omari, N. R. Birhashirwa, Yuma M'Keyo, Norbert Bagurubumwe Institut Congolais pour la Conservation de la Nature (ICCN), BP 852, Bukavu, République Démocratique du Congo.

Agenonga Upoki Faculté des Sciences, Université de Kisangani, Kisangani, République Démocratique du Congo.

Faustin Bengana Centre de Formation et de Recherche en Conservation Forestière (CEFRECOF), Epulu via Bunia, République Démocratique du Congo.

Mugunda Bashonga Centre de Recherches en Sciences Naturelles (CRSN), Lwiro via Bukavu, République Démocratique du Congo.

Received 1 September 1998. Accepted 24 April 1999 remarkable new species and subspecies, including the type specimen of the gorilla that now bears his name, Gorilla gorilla graueri (Plate 1). These first explorations were followed by other surveys that continued the discovery of new taxa, most notably of forest birds, adding to the documented biological richness of the region (Prigogine, 1971). Nearly half (83 species) of the total montane bird fauna of the African continent occurs in the Itombwe Massif, including 35 of 43 species and distinctive subspecies endemic to the Albertine Rift highlands and adjacent submontane forests (DowsettLemaire \& Dowsett, 1990; Butynski et al., 1997; Stattersfield et al., 1998). Itombwe is the only known location for the Congo bay owl Phodilus prigoginei, Schouteden's swift Schoutedenapus schoutedeni and Prigogine's nightjar Caprimulgus prigoginei. The first systematic surveys of gorillas in Itombwe in 1959 located 17 discrete areas of occurrence (Emlen \& Schaller, 1960). A recent global survey of Grauer's gorilla shows that Itombwe supports one of the most important concentrations of gorillas in eastern Congo (Hall et al., 1998a).

Most of the biological exploration of Itombwe was undertaken before independence in 1960, and was capped by Alexander Prigogine's monumental collections of the region's avifauna made between 1950 and 1967, totalling 565 species (Stubbs, 1988). In the years following independence, armed rebels occupied portions of the massif. Despite the potential for further discoveries, and its significance as one of the most 


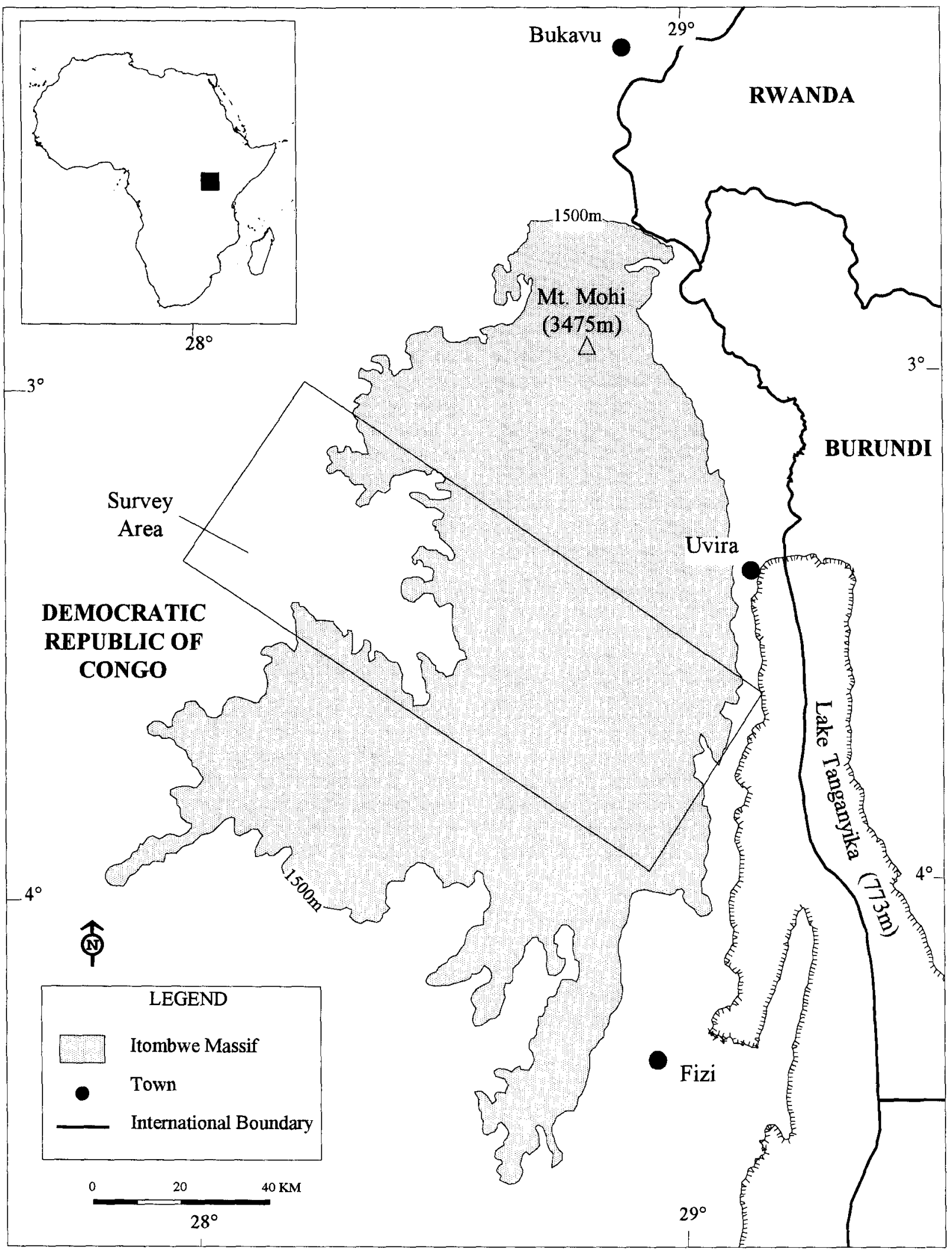

Fig. 1 The Itombwe Massif, Democratic Republic of Congo. In this paper, the Itombwe Massif is defined as that region above $1500 \mathrm{~m}$ in altitude. 


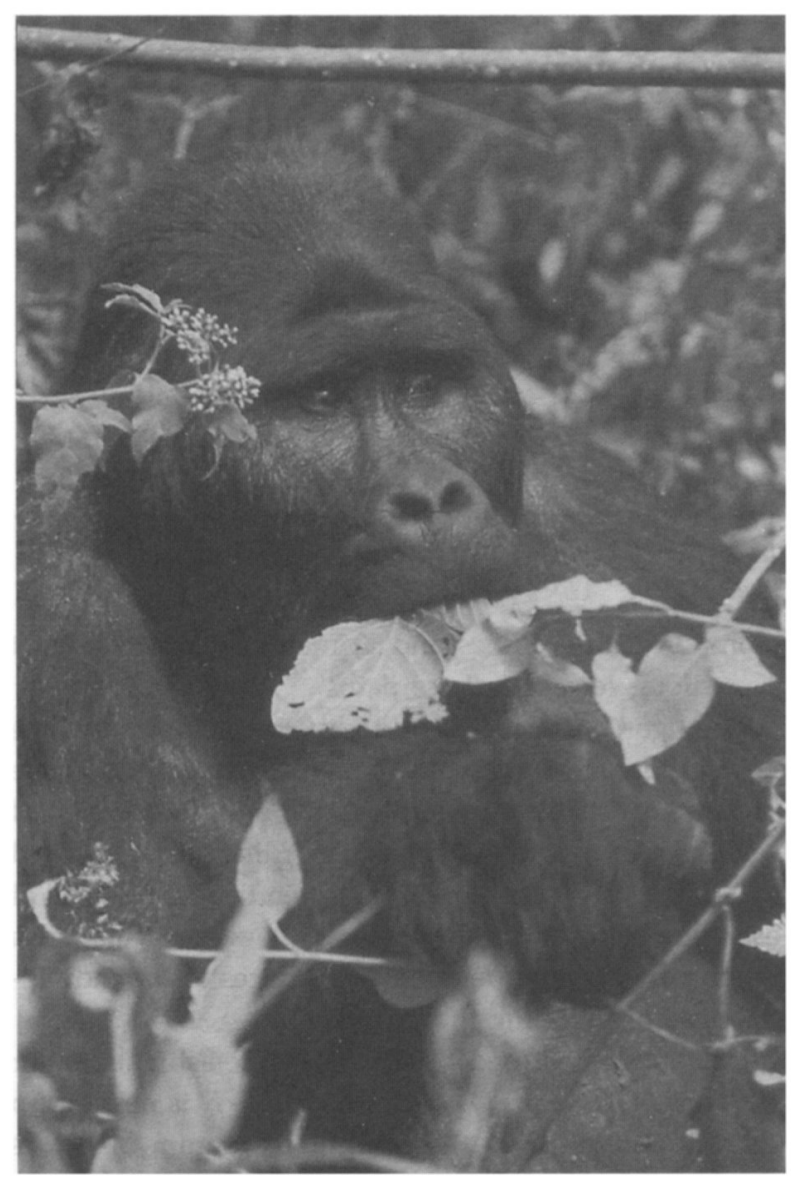

Plate 1 Grauer's gorilla Gorilla g. graueri, an Albertine Rift endemic subspecies (C Karl Ammann).

important forest areas for conservation in Africa (Prigogine, 1985; Collar \& Stuart, 1988; Stattersfield et al., 1998), no further fieldwork was undertaken during the following two decades.

Biological surveys were resumed in Itombwe in 1989, when Wilson \& Catsis (1990) made a brief reconnaissance trip to the northern and southern limits, during which they added one new bird species to Prigogine's $(1971,1978)$ list. Two years later, Hall \& Wathaut (1992) visited areas of Itombwe north of the Elila River to evaluate the status of gorilla populations and determine the feasibility of comprehensive surveys. They documented extensive habitat degradation, especially in the northern sectors, and found that several of the populations of gorillas that had been reported by Emlen \& Schaller (1960) in 1959 were extirpated. They concluded that Itombwe's fauna and large areas of its natural habitat were at risk.

This work was followed by brief field surveys (Schliter \& Doumenge, 1993; Sikubwabo, 1993; R. Beyers \& G. Debonnet, pers. comm.) that provided the first information from the more remote central portions of the massif, including observations of apparently high concentrations of gorillas in several areas. They also reported habitat degradation and heavy hunting pressure. All recent observers emphasized the urgent need to undertake more comprehensive biological surveys and to develop a conservation programme for the region.

In February 1996 field staff from the Institut Congolais pour la Conservation de la Nature (ICCN) and the Wildlife Conservation Society (WCS), in collaboration with colleagues from Zoo Atlanta, the University of Kisangani and Centre National de Recherche Scientifique (CNRS), initiated a 5-month biological and conservation survey in Itombwe. Fieldwork focused on two groups of taxa of high conservation significanceprimates, especially Grauer's gorilla, and bird species endemic to the Albertine Rift highlands (termed 'Albertine Rift endemic birds') - and on assessing the impact of human activities on the flora and fauna. Interviews with state and traditional authorities in the region and inhabitants in the massif were used to evaluate the political and socio-economic context of conservation options for the area.

This paper presents the results of these surveys, including:

- distribution, estimates of abundance and conservation status of gorilla populations over the entire massif;

- distribution and habitat associations of Albertine Rift endemic birds at selected sites in central and southern Itombwe; and

- a report on human exploitation of wildlife in the massif and the effect of human activities on natural habitats.

We conclude with recommendations for a conservation strategy in Itombwe in the context of the continuing political unrest that characterizes the region.

\section{Study region}

The intensive survey encompassed southern and central portions of Itombwe, an area of approximately $1600 \mathrm{sq} \mathrm{km}$ located at $3-4^{\circ} \mathrm{S}$, stretching from the Lake Tanganyika escarpment to $c \cdot 28^{\circ} \mathrm{E}$ in the west (Fig. 1). This area represents the central portion of the region included in Prigogine's (1978) demarcation of Itombwe, and contains the largest remaining areas of nondegraded natural habitats (Doumenge, 1998). Additional brief visits and interviews, conducted at settlements south of Mt Mohi and in the Fizi area, provided information on the status of gorilla populations in the northern and southern sectors of the massif.

Fieldwork was carried out from February to midJune 1996. The region was divided into six sectors (Fig. 2) and an initial reconnaissance was made in each 
Table 1 Itombwe Massif, Democratic Republic of Congo, survey coverage (1996); see Fig. 2 for locality of sectors

\begin{tabular}{|c|c|c|c|c|c|c|c|c|}
\hline \multirow[b]{3}{*}{ Sector } & \multirow{2}{*}{\multicolumn{2}{|c|}{ Survey coverage $(\mathrm{km})$}} & \multirow{3}{*}{$\begin{array}{l}\text { Altitude } \\
\text { range* } \\
(\mathrm{m})\end{array}$} & \multicolumn{2}{|l|}{ Surveys } & \multirow{3}{*}{$\begin{array}{l}\text { Birds } \\
\text { Observations }\end{array}$} & \multirow{3}{*}{$\begin{array}{l}\text { Mist- } \\
\text { nets }\end{array}$} & \multirow{3}{*}{$\begin{array}{l}\text { Human } \\
\text { impact }\end{array}$} \\
\hline & & & & \multirow{2}{*}{$\begin{array}{l}\text { Large mammals } \\
\text { Observations }\end{array}$} & \multirow[b]{2}{*}{ Collections } & & & \\
\hline & Transect & Reconnaissance & & & & & & \\
\hline A, West Mwana & 11.2 & 42.8 & $1000-1850$ & + & + & + & - & + \\
\hline B, East Mwana-South Elila & 14.5 & 215.0 & $1250-2200$ & + & + & + & - & + \\
\hline C, North Elila-South Kiandjo & 22.0 & 85.6 & $1250-2600$ & + & + & - & - & + \\
\hline D, North Kiandjo-South Kikuzi & 4.0 & 75.1 & $1000-2300$ & + & - & - & - & + \\
\hline E, North Kikuzi-South Ulindi & 10.5 & 60.3 & $1300-2400$ & + & - & - & - & + \\
\hline F, Sanje-Upper Mutambala & 0.0 & 53.6 & $1300-2800$ & + & + & + & + & + \\
\hline Total & 62.2 & 532.4 & & & & & & \\
\hline
\end{tabular}

* Altitudes from altimeter, Global Positioning System and available maps (SMGL, 1956).

sector to: contact local authorities; assess the status of habitats and the distribution of fauna; and identify areas for more intensive surveys. Surveys in each sector lasted 2-5 weeks and were conducted by one or more field teams that included locally hired porters and guides. Field teams specialized in different activities, including large-mammal inventories (with a focus on gorillas), ornithological surveys, and socio-economic and human-impact surveys.

During the course of the study, field teams logged a total of $594.6 \mathrm{~km}$ of transect and reconnaissance walks in the study region. Survey results were compiled on 1:200,000 mining company (Société Minière des Grands Lacs [SMGL]) maps. Satellite-derived (Geographic Positioning System [GPS]) locations were used to update maps and to locate selected survey locations, human settlements and landmarks. Table 1 summarizes the altitude range and survey coverage for each sector. Selected survey locations and landmarks are listed in Appendix 1.

\section{Methods}

\section{Gorillas and other mammals}

The distribution and estimates of abundance of gorillas and other large mammals were determined by counts of animals, or their sign (dung, night nests, trails and evidence of feeding), made from line transects and on reconnaissance walks along human footpaths. Methods followed those used in recent studies of apes, elephants and other large mammals in other forested areas of Africa (Barnes \& Jensen, 1987; Barnes et al., 1995; Hart \& Hall, 1996; Hall et al., 1997), with specific modifications for gorillas (Hall et al., 1998b). Distances along transects and on most reconnaissance walks were measured with a hip chain. Altitude and habitat descriptions, including dominant canopy-tree species and understorey composition, were made at $100-\mathrm{m}$ intervals along all transect lines and at major breaks in habitat type along reconnaissance paths.

The age (fresh, recent, old or very old) of each ape nest group encountered was recorded. Height above ground, construction materials used and the location of each nest in relation to the transect line were recorded for each nest in a group. The perpendicular distance of each nest group from the transect line was calculated as the mean of the perpendicular distances of the individual nests comprising the group.

Densities of weaned gorillas $(G)$ were estimated after Hall et al. (1998b) as $G=N S / D C$, where $N$ is nest group density derived from the computer program DISTANCE (Laake et al., 1994), $S$ is the mean number of nests per group (determined from observed nest groups classified as recent or fresh), $D$ is the estimated nest group decay rate, and $C$ is the daily night-nest construction rate per gorilla (assumed to be 1). Estimates of population size of weaned gorillas were obtained by multiplying estimates of weaned gorilla densities by the area occupied by gorillas.

Additional data on gorilla group sizes and numbers were obtained by following recent trails to night-nest sites. An effort was made to follow trails in different locations. Groups of nests differing in nest number were considered to belong to different groups of gorillas.

Counts of primates and the dung of elephant Loxodonta africana, buffalo Syncerus caffer, pig and antelope were also made on transects and reconnaissance surveys. Estimated age of all dung was recorded. Primate groups were identified to species, observed animals counted, and a note made if uncounted animals were likely to be present.

\section{Mammal collections}

When opportunities arose, field teams passing through settlements requested to see any skins and skulls and 


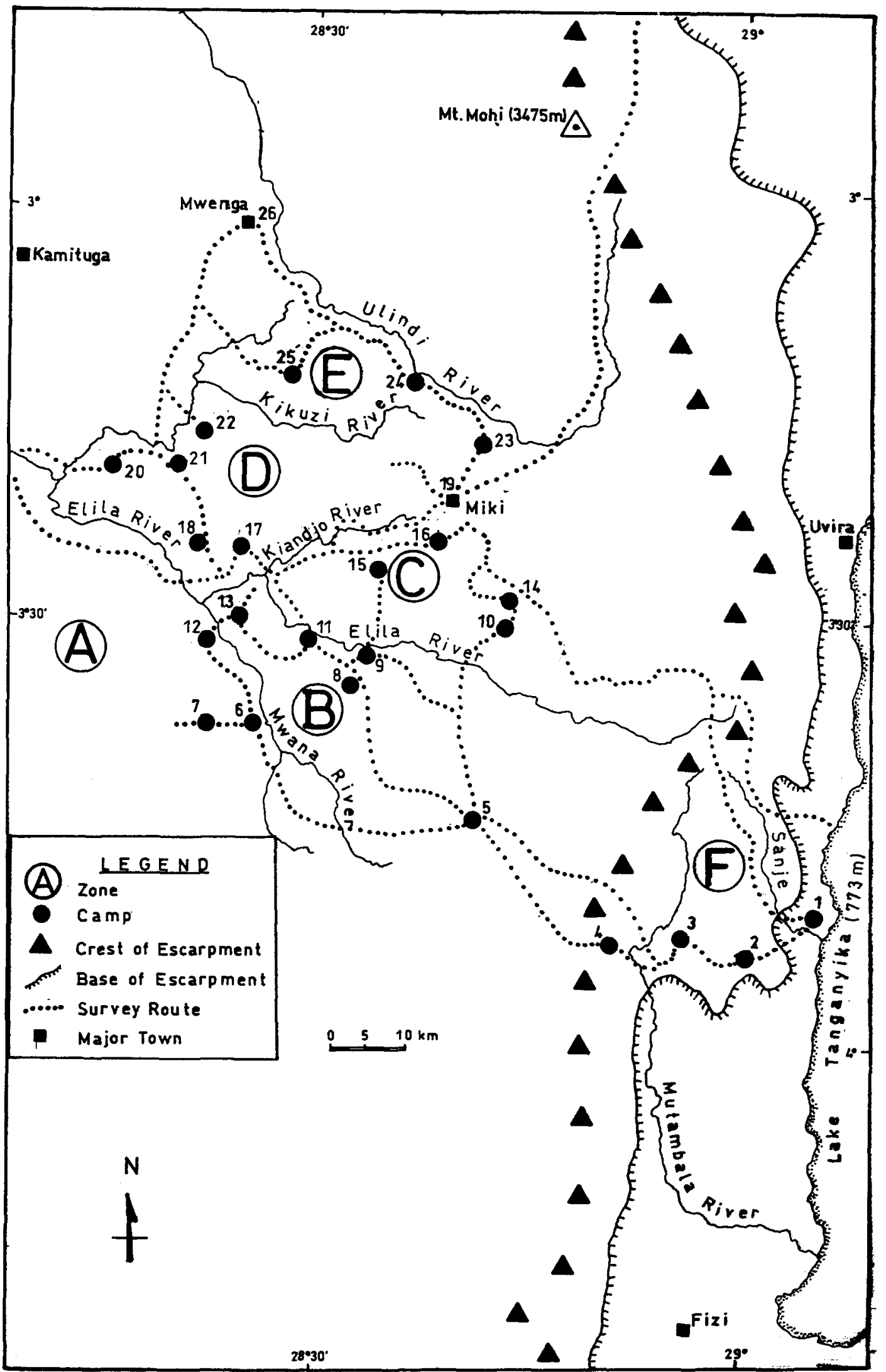

Fig. 2 Area of the 1996 survey of the Itombwe Massif, Democratic Republic of Congo. The six survey sectors (A-F) are identified in Table 1. The 26 numbered survey locations are identified in Appendix 1. Major survey routes only are indicated. 
noted their identity, and location and method of acquisition. Selected specimens were purchased and others were photographed. Catalogued specimens are housed at the ICCN provincial office in Bukavu.

\section{Bird surveys}

Data on birds were collected by systematic mist-net captures and intensive searches (bird walks) with visual identifications aided by call playbacks. Opportunistic observations were made during marches between sampling sites and on large-mammal survey transects. Mist-net samples of forest understorey birds were conducted at six sites in sector F. These covered three major habitat types ranging from light to heavy levels of habitat degradation. At each site, 12-20 standard (2.1-m-high) mist-nets were erected for 2-5 days. An effort was made to set nets at $50-\mathrm{m}$ intervals perpendicular to a transect crossing the site. Nets were unfurled from just before dawn ( 05.30 hours) until midlate afternoon, with the bottom panel as close to the ground as possible. Nets were checked at frequent intervals and all birds caught were measured (wing, tail, tarsus and beak lengths) and weighed. Presence of moult and brood patch were noted. All birds were banded with a numbered plastic band before release.

Intensive searches for birds were conducted in the same areas as the mist-net surveys and concentrated on non-understorey species. All birds seen or heard were recorded. Tape recordings of calls were made to document the occurrence of species and for instantaneous playback to aid in identification of unrecognized calls. We recorded location, altitude, habitat, height in vegetation, behaviour and association with other species.

\section{Human activities and conservation assessment}

Direct observations and interviews with local villagers were used to evaluate human impact on fauna and natural habitats. While on transects or reconnaissance walks we recorded observations of snares, polecutting, pit-sawing, paths, mining sites and agricultural clearings. Major markets in the region were visited on one or more occasions and the occurrence of forest products, in particular wild meat, was noted.

Two members of the team held meetings with traditional leaders, state administrators and local people in the area covered by the survey to solicit their observations on fauna and flora, and their perceptions on the need for conservation. In addition to formal organized encounters, contacts with guides and porters employed by field teams, and impromptu contacts with local farmers, hunters and authorities, provided information on human-wildlife interactions.

\section{Results}

\section{Habitats surveyed}

Itombwe lies between 750 and $3475 \mathrm{~m}$ at the southern limit of the equatorial forest block. Annual rainfall varies from $1200 \mathrm{~mm}$ at the eastern limit of the escarpment to over $2400 \mathrm{~mm}$ in the northern and central sectors (Prigogine, 1978). The wide range of topography, underlying geology and rainfall give rise to a remarkable diversity of local environmental conditions, including a variety of habitats and ecotones not widely represented elsewhere on the continent. Among the most striking are montane forest and savannah mosaics, bamboo galleries in high-altitude moorlands, and a miombo woodland (dominated by at least one Brachystegia sp.) and montane moist forest transition. Habitats over almost half of the massif, including large areas at the highest altitudes along the escarpment, have been extensively modified and degraded by human activities in the recent past (Fig. 3).

Itombwe rises abruptly along the eastern escarpment of Lake Tanganyika. Figure 4 shows a $120-\mathrm{km}$ profile of altitude, major habitat types and transitions within the survey area. Between 900 and $1700 \mathrm{~m}$ the vegetation changes from Hyparrhenia savannah to patches of miombo woodland dominated by Michelsonia sp. and Brachystegia sp. At about $1700 \mathrm{~m}$, the miombo woodlands give way to montane forest dominated by Parinari excelsa, Symphonia globulifera, Carapa grandifolia and Macaranga spp., intermixed with stands of tree fern Cyathea maniana and broken by occasional grassy clearings and regenerating bush. Patches of bamboo Arundinaria alpina begin to appear in the montane forest above $1900 \mathrm{~m}$, and merge into monodominant bamboo stands towards the crest of the escarpment between 2400 and $2800 \mathrm{~m}$. West of the escarpment the formerly extensive stands of bamboo and montane forest have been seriously degraded over the last three decades by agricultural and pastoral incursions.

About $30 \mathrm{~km}$ west of the lake, the forested slopes give way abruptly to a high $(1900-2300 \mathrm{~m})$ plateau of open grasslands. This plateau represents a major northward extension of the Katangan savannahs, broken only by occasional Cyperaceae-dominated swamps and narrow galleries of montane forest along some watercourses. These highland prairies, now heavily grazed by domestic cattle, extend for over $10 \mathrm{~km}$ from east to west, and separate the forested mountains of the Lake Tanganyika escarpment from those of the Elila River basin to the west.

About $50 \mathrm{~km}$ west of the lake, the gallery forests coalesce, forming a mosaic of montane forests and highland prairies. These give way to an unbroken 


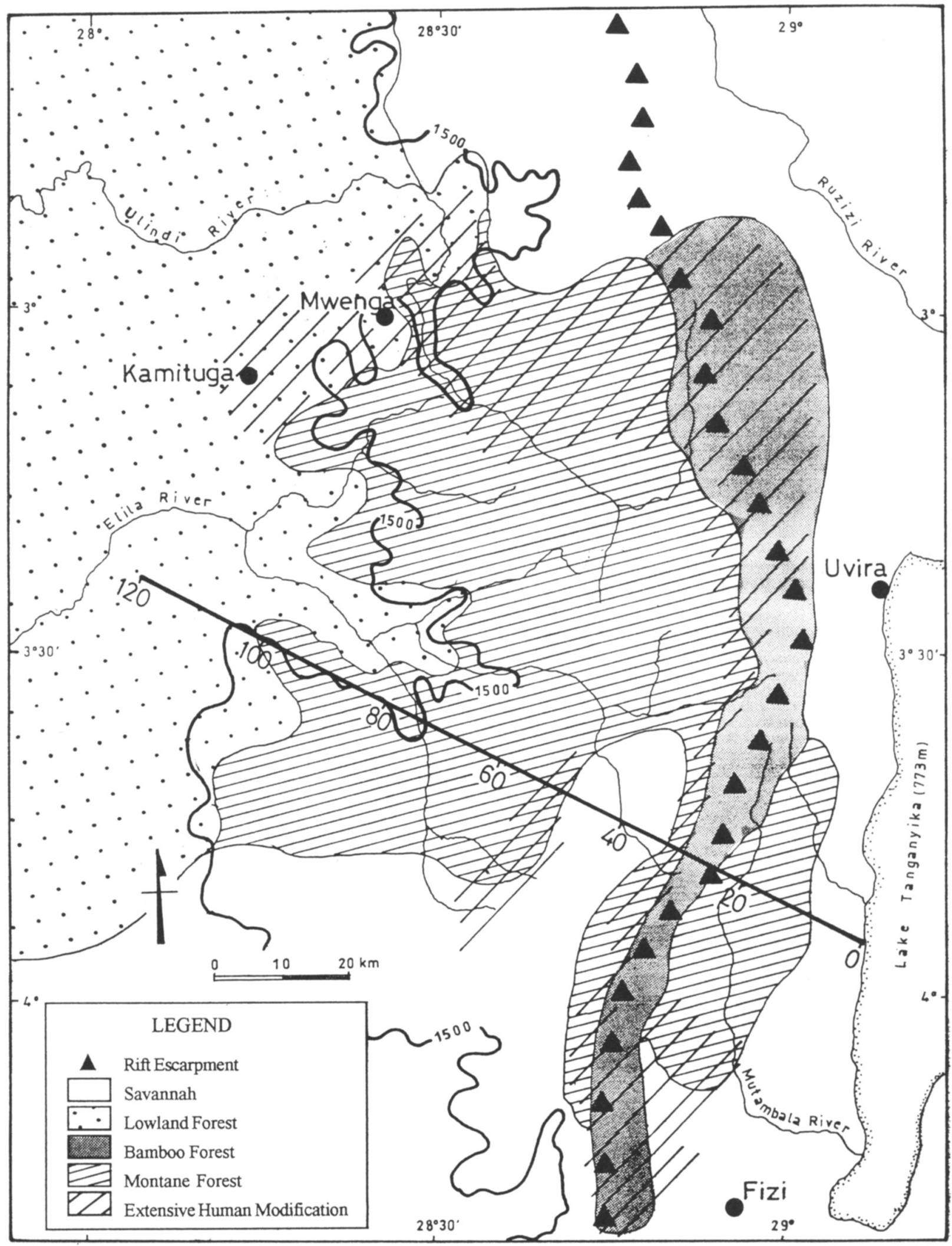

Fig. 3 Major habitats of the Itombwe Massif, Democratic Republic of Congo. The heavy line indicates the location of the habitat profile in Fig. 4, with distance from Lake Tanganyika shown in kilometres. 


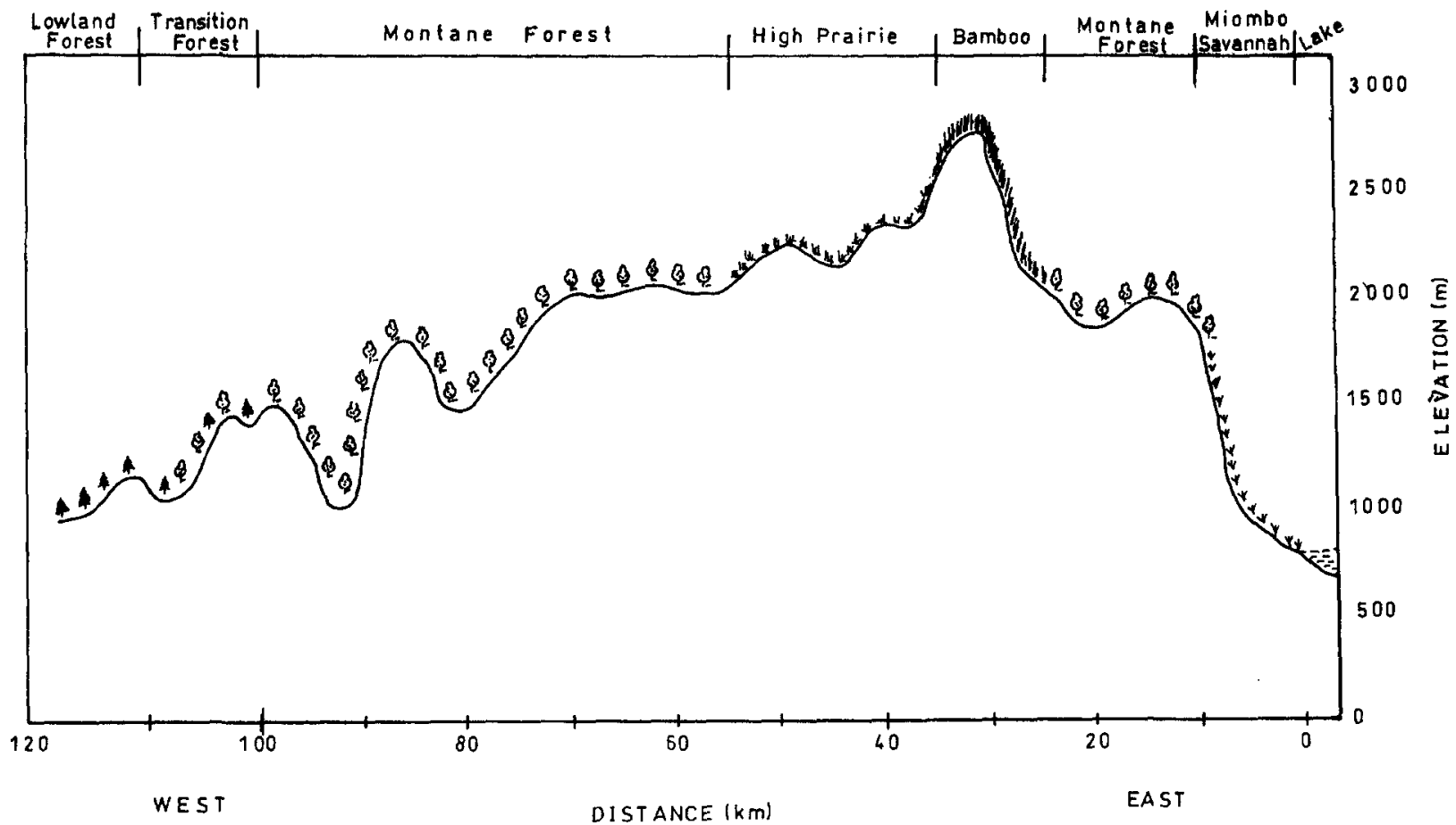

Fig. 4 Habitat profile of survey area in the Itombwe Massif, Democratic Republic of Congo. The location of this profile is shown in Fig. 3. Vegetation formations and dominant tree species are described in the text.

montane forest between 1600 and $1900 \mathrm{~m}$ dominated by Lebrunia bushaie, Beilschmiedia sp., Ocotea sp., Syzygium spp., Grewia milbraedi, Tabernaemontana spp. and $\mathrm{Mu}$ - sanga leo-errerae, with frequent stands of tree ferns. As the forested slopes descend westward, the forest canopy diversifies with the addition of many lowland

Table 2 Population estimates of gorilla Gorilla gorilla graueri in the Itombwe Massif, Democratic Republic of Congo (1996); see Fig. 5 for map of gorilla areas

\begin{tabular}{|c|c|c|c|c|c|c|c|c|c|}
\hline \multirow[b]{2}{*}{$\begin{array}{l}\text { Gorilla } \\
\text { area }\end{array}$} & \multirow[b]{2}{*}{ High-density zones } & \multirow[b]{2}{*}{$\begin{array}{l}\text { Areas occupied } \\
\text { by gorillas } \\
\text { (sq km) }\end{array}$} & \multicolumn{3}{|c|}{ Gorilla observations } & \multicolumn{3}{|c|}{ Gorilla population estimates } & \multirow[b]{2}{*}{ Notes } \\
\hline & & & $\begin{array}{l}\text { No. } \\
\text { nest } \\
\text { sites }\end{array}$ & $\begin{array}{l}\text { Total } \\
\text { no. } \\
\text { nests }\end{array}$ & $\begin{array}{l}\text { No. } \\
\text { individuals } \\
\text { seen }\end{array}$ & $\begin{array}{l}\text { Low- } \\
\text { density } \\
\text { zones }\end{array}$ & $\begin{array}{l}\text { High- } \\
\text { density } \\
\text { zones }\end{array}$ & Total & \\
\hline 1 & $\begin{array}{l}\text { North Kabembwe, } \\
\text { Upper Sanje Valley }\end{array}$ & 230 & 2 & 9 & 0 & 19 & 46 & 65 & \\
\hline 2 & Ibachilo, Ngomiano & 250 & 7 & 20 & 2 & 23 & 28 & 51 & \\
\hline 3 & $\begin{array}{l}\text { Kabelukwa, Kitibingi, Mt } \\
\text { Kasondjo }\end{array}$ & 300 & 20 & 79 & 6 & 18 & 142 & 160 & \\
\hline 4 & Mt Lungjei, Mt Ibenga & 100 & 6 & 41 & 0 & 20 & 82 & 102 & \\
\hline 5 & Kapanga, Kiandjo & 230 & 20 & 84 & 0 & 45 & 170 & 215 & \\
\hline 6 & Mt Kipapa & $?$ & 0 & 0 & 0 & $?$ & $?$ & $?$ & $\begin{array}{l}\text { Feeding } \\
\text { sign } \\
\text { only }\end{array}$ \\
\hline 7 & Lueno, Milanga & 40 & 1 & 3 & 0 & 5 & 22 & 27 & \\
\hline 8 & Mt Ngusa, Mt Nolabi & $?$ & 0 & 0 & 0 & $?$ & $?$ & $?$ & $\begin{array}{l}\text { Feeding } \\
\text { sign } \\
\text { only }\end{array}$ \\
\hline 9 & Kakanga & $?$ & 0 & 0 & 0 & $?$ & $?$ & $?$ & $\begin{array}{l}\text { Feeding } \\
\text { sign } \\
\text { only }\end{array}$ \\
\hline 10 & Nzombe & 180 & 23 & 104 & 0 & 30 & 207 & 237 & \\
\hline Totals & & 1330 & 79 & 340 & 8 & 160 & 697 & 857 & \\
\hline
\end{tabular}




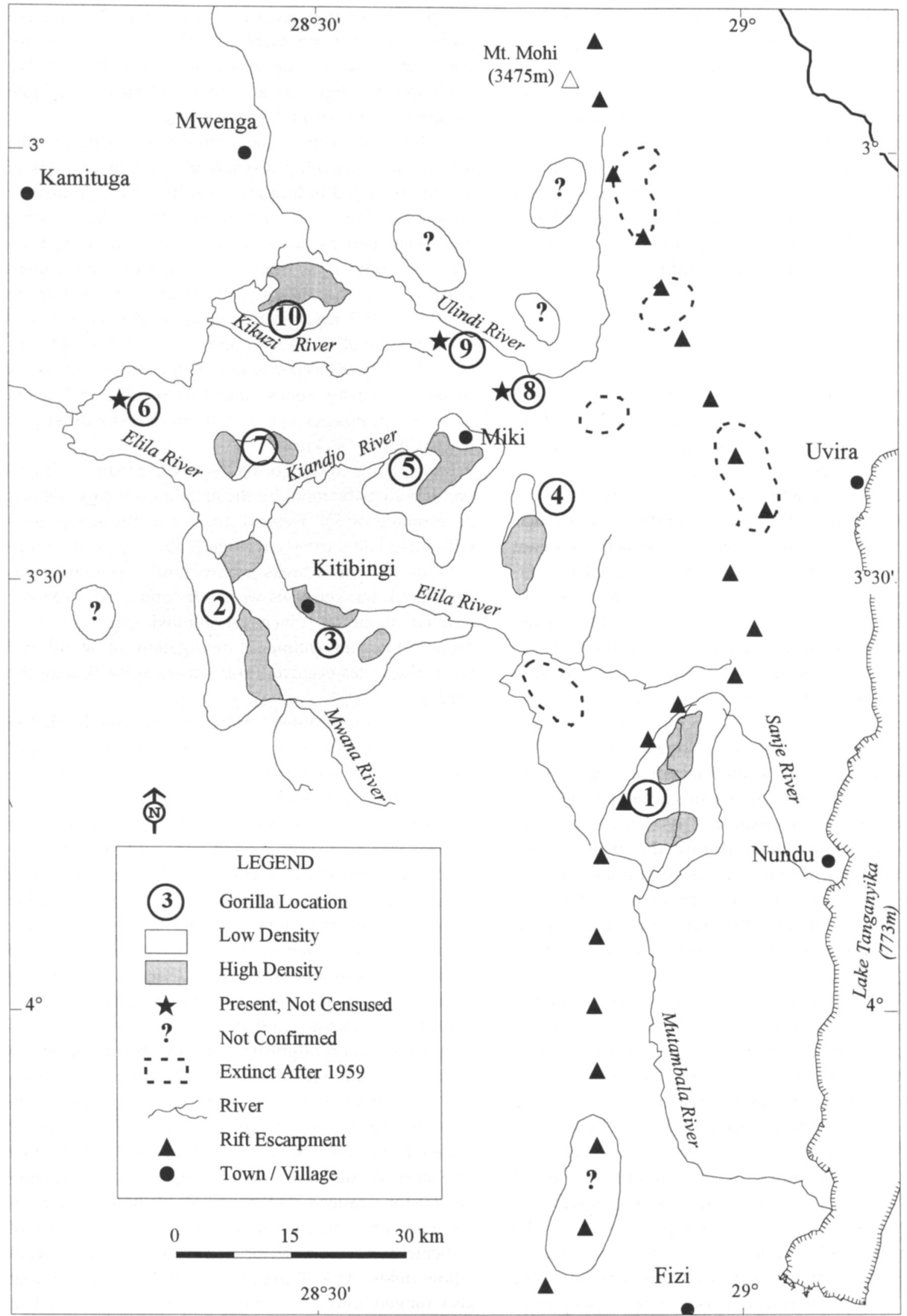

Fig. 5 Distribution of Grauer's gorilla Gorilla gorilla graueri in the Itombwe Massif, Democratic Republic of Congo (1996). Areas occupied by gorillas are identified in Table 2.

(․ $1999 \mathrm{FFI}$, Oryx, 33(4), 301-322 
species, including Cleisthanthus sp., Albizia spp., Michelsonia microphylla, Cynometra alexandri, Uapaca spp. and Gilbertiodendron dewevrei. This submontane forest dominates the uninhabited ranges $(1200-1500 \mathrm{~m}$ altitude) west of the Mwana River $80-100 \mathrm{~km}$ west of Lake Tanganyika. About $100 \mathrm{~km}$ west of the lake, the massif drops off to under $1200 \mathrm{~m}$ and the submontane forest gives way to lowland moist forest that extends west to the Congo River. Doumenge (1998) provided tree species composition on three vegetation plots in northern Itombwe and a vegetation profile extending west from Lake Tanganyika at $3^{\circ} 30^{\prime} \mathrm{S}$.

\section{Gorillas}

Ten areas were identified in which gorillas or their sign were recorded during the survey (Fig. 5, Table 2). These included eight of the areas first identified by Emlen \& Schaller (1960), plus two areas - the upper Mutambala watershed (area 1) and the mountains west of the Mwana River (area 2)-where gorilla presence was suspected in the earlier survey but which were not confirmed as gorilla areas. The area occupied by gorillas in seven areas where gorilla numbers were censused during this study was estimated at $1330 \mathrm{sq} \mathrm{km}$. The total area occupied by the three populations where survey coverage was incomplete (areas 6,8 and 9) is likely to be less than $200 \mathrm{sq} \mathrm{km}$ (Table 2).

At least five of the 17 gorilla locations first recorded by Emlen \& Schaller (1960) no longer have gorillas. Most of these areas are located in north-eastern Itombwe where habitat loss, in particular to pastoral encroachment, has been greatest. The current status of four populations identified during the 1959 surveys remains uncertain. Recent reports of gorillas north of the Ulindi River and near Fizi in southern Itombwe must be verified. The possible occurrence of gorillas in transition and lowland forest west of area 2 also remains to be verified.

A total of 79 groups of gorilla night nests totalling 340 individual nests was recorded during the survey. Twenty-seven fresh or recent nest groups had an average group size of 6.4 nests (range 1-14 nests/group). This figure is the same as the mean nest group size recorded in the lowland sector of Kahuzi-Biega National Park (Hall et al., 1998b). Excluding 21 censused nest groups, which might have represented repeated counts of the same gorilla group, and multiplying by mean group size, the survey sample represents the nests of at least 371 weaned individuals.

Forty-five per cent of the nests were constructed of predominantly herbaceous materials with 33 per cent of nest sites containing only herbaceous nests. The proportion of herbaceous nests in the Itombwe sample was comparable to that recorded in a sample of western gorilla nests in Lopé, Gabon, by Tutin et al. (1995), for which mean decay rate was estimated as 78 days. We have used this figure as an estimate of mean decay rate of Itombwe gorilla nest groups.

Within each of the areas occupied by gorillas, gorilla activity was unevenly distributed, with high levels of activity recorded in locations classified as 'high-density zones', and low levels of sign recorded in surrounding areas classified as 'low-density zones'. Lumping transect nest-count data from 11 high-density zones identified during the survey yielded an estimated mean density of 45.2 nest groups per sq km (95 per cent confidence interval, 25.1-81.5) and a mean estimated density of 3.7 gorillas per sq km. Estimated densities in seven low-density zones ranged from 1.5 to 15.2 (mean 3.6) nest groups per $\mathrm{sq} \mathrm{km}$, with an average density of 0.3 gorillas per $\mathrm{sq} \mathrm{km}$.

Multiplying mean gorilla-density estimates in highand low-density zones by the area of each zone yielded an estimate of 857 weaned gorillas in the seven areas with adequate survey coverage (Table 2). Gorilla numbers in the three areas where gorilla presence was confirmed, but censuses were not conducted, probably totalled about 60 , given the limited extent of these areas. Thus, an estimated population of about 900 weaned gorillas occurred in Itombwe at the time of the survey.

Areas of concentrated gorilla activity were located in secondary vegetation in the vicinity of villages (eight areas), abandoned mining areas (three areas) and on steep mountain slopes where the canopy was broken by frequent clearings (six areas). In the upper Mutambala region (area 1), gorillas ranged from altitudes of $1800-$ $2600 \mathrm{~m}$ and exploited a variety of habitats, including montane forest, highland prairie mosaic, regenerating fallow gardens and monodominant stands of bamboo. Local informants reported that the use of bamboo stands was seasonal, suggesting that, in this area at least, gorillas may make seasonal movements across an altitude and habitat gradient.

The association of gorillas with inhabited villages, in particular in the vicinity of Ibachilo, Kitibingi and Kabelukwa (areas 2 and 3), and their near absence in adjacent mature forest supports the observations of Emlen \& Schaller (1960) and Hall et al. (1998b) that undisturbed montane forests represent low-quality habitat for Grauer's gorillas. At all of these sites, gorillas were often located in the immediate outskirts of settlements where they foraged in gardens and recent fallow fields. At Kitibingi, we recorded one group that also ranged into Pennisetum savannah and nested at night in high grass. Based on reports of the villagers, the associations of gorillas with these settlements have 


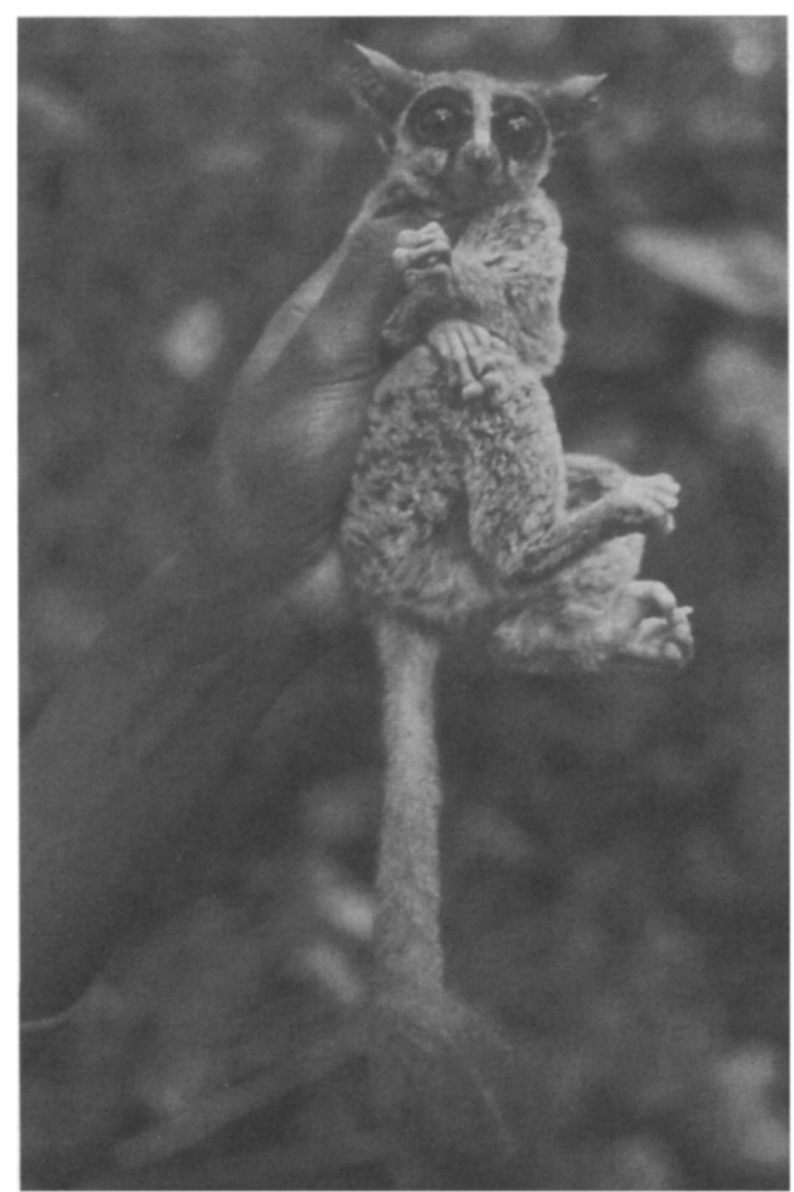

Plate 2 Spectacled galago Galago matschiei, an Albertine Rift endemic species (C) Tom Butynski).

been remarkably stable, in some cases persisting for over 60 years.

The occurrence of gorillas across a variety of vegetation types and human impact in Itombwe suggests a high degree of behavioural flexibility by Grauer's gorilla in adapting to sometimes unique local conditions. This argues strongly for efforts to protect as many of the local populations as possible to ensure the conservation of the full range of biological, and perhaps cultural, diversity within this region.

\section{Other mammals}

A total of 56 species of mammals was recorded on the survey (see Appendix 2). Sixty-one mammal specimens (skins or skulls) were collected and additional specimens were photographed. Noteworthy additions to the known mammalian fauna (Wilson \& Catsis, 1990) include four species of prosimians found in sector F (Fig. 2): the greater galago Otolemur crassicaudatus, observed in miombo woodlands at $1200 \mathrm{~m}$; a spectacled galago Galago matschiei (Plate 2), caught in a mist-net in bam- boo forest at $2300 \mathrm{~m}$; and Thomas's galago Galagoides thomasi and Demidoff's galago Galagoides demidoff, both tape-recorded at a number of locations between 1750 and $2000 \mathrm{~m}$. Previously, the only recorded prosimian for Itombwe was potto Perodicticus potto. Another primate that may occur in Itombwe is the owl-faced monkey Cercopithecus hamlyni, described by local villagers, but not observed.

Sign and sightings of most larger mammals, ungulates and primates were uncommon. Elephant dung was found on only 12 occasions in four survey sectors. Buffalo were found in four sectors, all in areas of regenerating vegetation, including abandoned mines. We found no buffalo sign on the savannahs in Itombwe. Densities of monkeys were low, with mean encounter rates on transects of 0.1 groups per $\mathrm{km}$. Monkeys were generally silent and frequently fled when encountered, indicating heavy hunting pressure. A total of 48 chimpanzee Pan troglodytes nest groups ( 0.78 nest sites per $\mathrm{km}$ of transect, mean 2.3 nests per group) were recorded. Comparable encounter rates were associated with a density of 0.4 chimpanzees per sq $\mathbf{k m}$ in the Kahuzi-Biega National Park (Hall et al., 1998b). Chimpanzee nest groups were recorded in all six survey sectors over an area of about $2800 \mathrm{sq} \mathrm{km}$, providing a preliminary estimate of 1100 chimpanzees for the area surveyed.

\section{Birds}

A total of 248 species of birds was identified during the survey, including 23 species not previously recorded for the massif by Prigogine (1971, 1978), bringing the total number of bird species known for Itombwe to 588 . Of the additions, five species were found in miombo woodlands, a habitat not surveyed by Prigogine. An additional six species were recorded in savannah and agricultural environments on the eastern flank of the Lake Tanganyika escarpment. Twelve of the additions, however, were recorded in the montane forests and the high plateau surveyed by Prigogine's collectors (see Appendix 3).

Twenty-two of the 35 species and subspecies of birds endemic to the montane and submontane forests of the Albertine Rift were observed during the survey (Table 3). One Congo bay owl was netted. This owl was previously known from a single specimen collected in Itombwe almost 50 years ago (Butynski et al., 1997). Most of the endemic species were observed above $1800 \mathrm{~m}$ and a number were recorded on only one side of the savannah plateau. Some of these species were probably overlooked on the less intensive surveys west of the plateau. However, the yellow-eyed black flycatcher Melaenornis ardesiaca, yellow-crested helmet 
Table 3 Observations of Albertine Rift montane endemic birds in the southern Itombwe Massif, Democratic Republic of Congo (1996)

\begin{tabular}{|c|c|c|c|c|}
\hline \multirow[b]{2}{*}{ English name } & \multirow[b]{2}{*}{ Scientific name* } & \multicolumn{2}{|l|}{ Occurrence } & \multirow[b]{2}{*}{ Altitude $(\mathrm{m})$} \\
\hline & & Rift escarpment & Western highlands & \\
\hline Handsome francolin & Francolinus nobilus & + & - & $>2250$ \\
\hline Congo bay owl & Phodilus prigoginei & + & - & 1900 \\
\hline Rwenzori nightjar & Caprimulgus ruwenzorii & + & - & $1800-2000$ \\
\hline Dwarf honeyguide & Indicator pumilio & + & - & 2000 \\
\hline Red-collared flycatcher babbler & Kupeornis rufocinctus & - & + & $1800-1900$ \\
\hline Grauer's warbler & Graueria vittata & + & - & $1800-1900$ \\
\hline Neumann's short-tailed warbler & Hemitesia neumanni & + & + & $1800-2350$ \\
\hline Red-faced warbler & Phylloscopus laetus & + & + & $1800-2350$ \\
\hline Rwenzori apalis & Apalis (pulchra) ruwenzorii & + & + & $1750-1950$ \\
\hline Mountain masked apalis & Apalis personata & + & + & $1750-2300$ \\
\hline Red-throated alethe & Alethe poliophrys & + & - & $1700-2350$ \\
\hline Archer's robin chat & Cossypha archeri & + & + & $1700-2350$ \\
\hline Kivu ground thrush & Zoothera tanganjicae & + & - & $1800-1950$ \\
\hline Yellow-eyed black flycatcher & Melaenornis ardesiaca & - & + & $1800-2200$ \\
\hline Rwenzori puffback flycatcher & Batis diops & + & + & $1800-2350$ \\
\hline Yellow-crested helmet shrike & Prinops alberti & - & + & $1800-1900$ \\
\hline Stripe-breasted tit & Parus fasciiventer & + & - & $2100-2300$ \\
\hline Blue-headed sunbird & Nectarinia alinae & + & + & $1850-2350$ \\
\hline Regal sunbird & Nectarinia regia & + & + & $1900-2350$ \\
\hline Purple-breasted sunbird & Nectarinia purpuriventris & + & - & $>1950$ \\
\hline Strange weaver & Ploceus alienus & + & - & $1850-2100$ \\
\hline Dusky crimson wing & Cryptospiza jacksoni & + & + & $1800-2350$ \\
\hline
\end{tabular}

* Scientific names follow Dowsett-Lemaire \& Dowsett (1990) and Dowsett \& Forbes-Watson (1993).

shrike Prinops alberti and the red-collared flycatcher babbler Kupeornis rufocinctus were recorded on multiple occasions west of the plateau but not in the east. These conspicuous species appeared to be absent from the forest sites surveyed along the Lake Tanganyika escarpment.
Table 4 summarizes the results of the mist-net inventories of understorey forest birds in sector F. Six sites between 1750 and $2350 \mathrm{~m}$ ranging from lightly degraded to heavily degraded montane forest and bamboo, and two sites with forest and pasture mosaic were surveyed. A total of 419 birds of 56 species was cap-

Table 4 Mist-net captures of understorey birds in the southern Itombwe Massif, Democratic Republic of Congo (1996)

\begin{tabular}{|c|c|c|c|c|c|c|c|}
\hline Site & Kanguli & Bamboo & Kilumbi & Milimba & Kabembwe 1 & Kabembwe 2 & Total \\
\hline Altitude (m) & 1950 & 2350 & 1900 & 1850 & 1750 & 1900 & - \\
\hline Habitat & $\begin{array}{l}\text { Montane } \\
\text { forest }\end{array}$ & Bamboo & $\begin{array}{l}\text { Montane } \\
\text { forest }\end{array}$ & $\begin{array}{l}\text { Montane } \\
\text { forest } \\
\text { with tree fern }\end{array}$ & $\begin{array}{l}\text { Forest } \\
\text { and pasture } \\
\text { mosaic }\end{array}$ & $\begin{array}{l}\text { Forest } \\
\text { and pasture } \\
\text { mosaic }\end{array}$ & \\
\hline Level of degradation & Light & Light & Moderate & Light & Moderate & Heavy & - \\
\hline Nets & 12 & 14 & 20 & 13 & 20 & 15 & 94 \\
\hline Days & 4 & 2 & 3 & 4 & 5 & 4 & 22 \\
\hline Metre-net-hours* & 4512 & 2503 & 6624 & 5519 & 12,793 & 5070 & 37,021 \\
\hline Captures/100 m-net-hours & 2.35 & 1.60 & 0.77 & 0.92 & 0.63 & 1.79 & 1.13 \\
\hline Species captured & 23 & 13 & 21 & 34 & 25 & 25 & 56 \\
\hline Birds captured & 106 & 40 & 51 & 51 & 80 & 91 & 419 \\
\hline Endemic species captured $\dagger$ & 8 & 6 & 6 & 13 & 7 & 2 & 13 \\
\hline Endemic birds capturedt & 35 & 22 & 15 & 15 & 30 & 5 & 122 \\
\hline $\begin{array}{l}\text { Per cent endemic species cap- } \\
\text { turedt }\end{array}$ & 34.8 & 46.2 & 28.6 & 38.2 & 28.0 & 8.0 & 23.2 \\
\hline $\begin{array}{l}\text { Per cent endemic birds } \\
\text { capturedt }\end{array}$ & 33.0 & 55.0 & 29.4 & 29.4 & 37.5 & 5.5 & 29.1 \\
\hline
\end{tabular}

* Length of mist-nets $(\mathrm{m}) \times$ hours in operation summed for all mist-nets used.

+ Birds restricted to the highlands of the Albertine Rift. 
tured, of which 13 (23.2 per cent) were Albertine Rift endemics (Plates 3-5). Capture rates varied from 0.92 to 2.35 birds/100-m-net-hours. Highest capture rates were in lightly degraded forest at $1950 \mathrm{~m}$ and in heavily degraded forest and pasture mosaic at $1900 \mathrm{~m}$. The contribution of Albertine Rift endemics to the catch was higher at undisturbed sites than at degraded sites. Fifty-five per cent of all captures, and 46 per cent of all species caught in a lightly degraded bamboo forest (2350 m) were Albertine Rift endemics. Endemics comprised 28-35 per cent of all species, and 29-38 per cent of all individuals captured in four lightly to moderately degraded sites between 1750 and $1950 \mathrm{~m}$. In contrast, only 6.5 per cent of all species and 8 per cent of captures were endemics at the heavily degraded site at the same altitude.

\section{Human impact on the fauna and flora}

The human population in the three administrative territories that include the Itombwe Massif-Uvira, Mwenga and Fizi-was estimated at 757,000 in 1994 (Omari, 1997). Most of the population occurs in the urban centres of the region (Uvira, Fizi, Baraka, Kamituga, Mwenga and Lemera), and along the base of the Rift escarpment near Lake Tanganyika. Within Itombwe, population densities are highest in the north and east, and lowest in the south-west, with almost no permanent settlements west of the Mwana River. Population densities in the Territories of Fizi and Mwenga increased 22 per cent over the 6-year period from 1988 to 1994 (Fizi Territory, from 11.6 to 14.0 inhabitants per sq km; Mwenga Territory, from 17.7 to 22.0 inhabitants per sq $\mathrm{km}$ ). This population growth was concentrated along Lake Tanganyika, while many areas in the Itombwe highlands lost population to emigration.

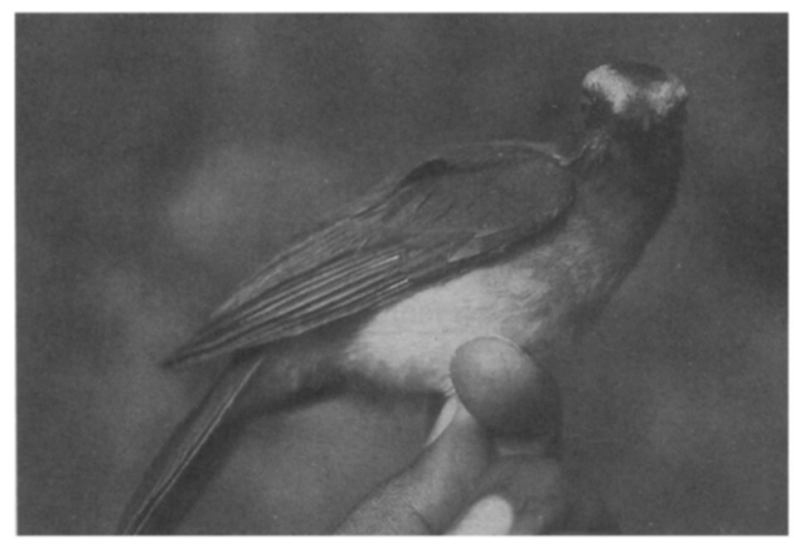

Plate 3 Red-throated alethe Alethe poliophrys, an Albertine Rift endemic species (C) Tom Butynski).
The distribution of human activities that have a major impact on forest habitats and their faunas is shown in Fig. 6. The relative frequency of occurrence of human activities recorded on transects and reconnaissance surveys in each sector is given in Table 5 .

Hunting was recorded at high levels in all but the Sanje/Mutambala sector. Snares are the most frequently used hunting method in Itombwe. A wide variety of species was reported to be hunted, including arboreal species. Most of the snares observed in the forest were set for muroid rodents, pouched rats Cricetomys eminii, squirrels and brush-tailed porcupines Atherurus africanum. Little effort was made to target ungulates in most areas, supporting our observations that populations of larger game were very low. Shotguns were recorded in all survey sectors, although these were used less frequently than snares. Poachers with access to military arms were reported to have killed elephants over the last 5 years, but this appears to occur infrequently at present because elephant populations are now extremely low. We recorded major bush-meat markets at Miki, Mulamboze, Mwenga and Kamituga, which sold animals taken from over most of the massif. We encountered market hunters in the forests west of the Mwana River who reported that they had travelled more than $50 \mathrm{~km}$ to shoot monkeys.

Shifting cultivation was recorded in all areas of the massif except in parts of the extreme south-west. Evidence of earlier agricultural clearing, including secondary forests and small patches of Pennisetum savannah, was recorded in most survey areas. Settlement relocation continues at the present time. A number of the villages recorded by Prigogine (1978) were no longer situated in their originally mapped position. Some were displaced by one to several kilometres, while others appeared to have been completely disbanded. Gardens in the west of the survey zone (sectors A, B and D) were small $(<0.5-2.0 \mathrm{ha})$, with manioc being the principal crop. Most active gardens were opened in previously cleared areas with few located in primary forest. In eastern Itombwe (sectors C and F), maize was the principal subsistence crop and garden sizes were much larger (up to 5 ha in some cases). The widespread occurrence of a maize blight in the massif since the early 1990s has led to an expanding agricultural front as farmers seek to compensate for declining yields by planting larger gardens in new areas. Major areas of gallery forest along both edges of the central savannah plateau, including the location where the Congo bay owl was rediscovered, are being degraded as a result.

Creation of new pastures for cattle by burning and forest clearing pose a major threat to Itombwe's forests, in particular at the higher altitudes along the Rift 


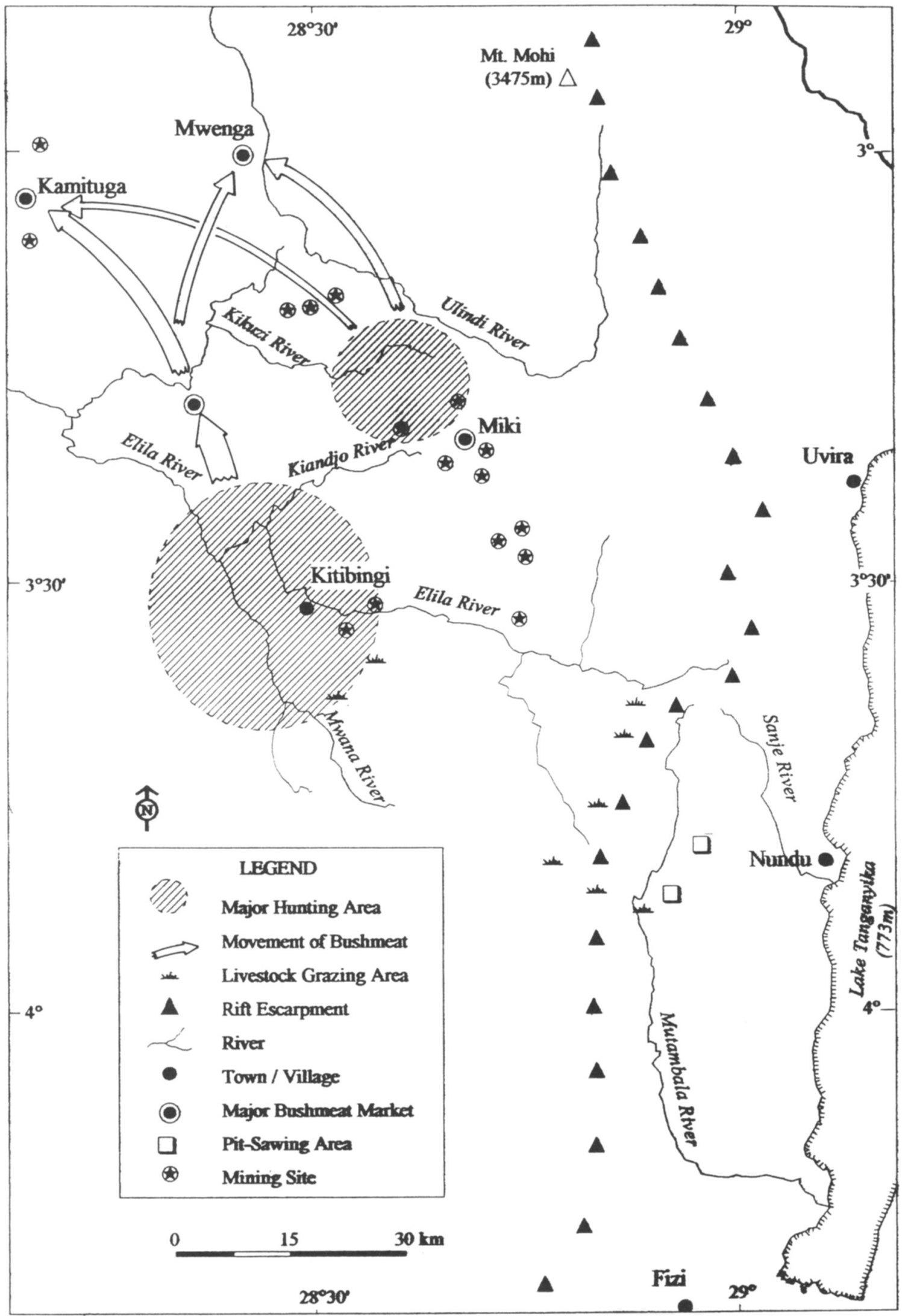

Fig. 6 Distribution of human activities that have an impact on flora and fauna in the Itombwe Massif, Democratic Republic of Congo (1996). 


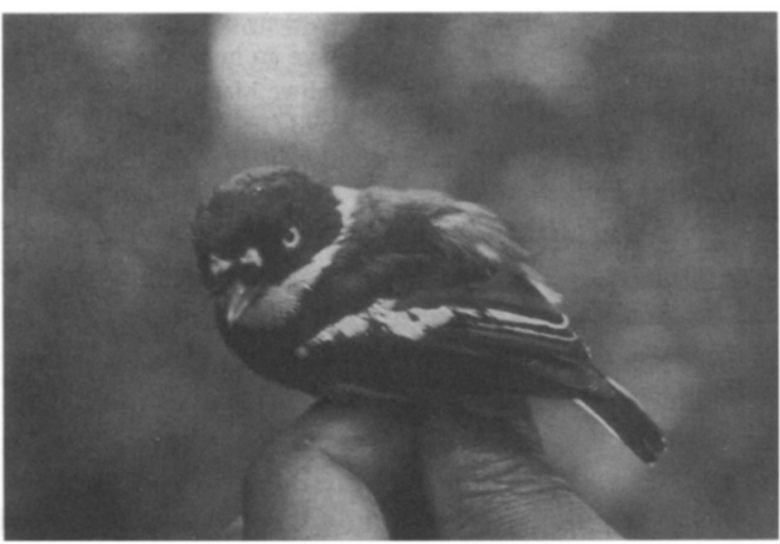

Plate 4 Ruwenzori puffback flycatcher Batis diops, an Albertine Rift endemic species (C Tom Butynski).

escarpment. Much of the pasture showed signs of overgrazing, indicating significant pastoralist expansion into new areas. Continued political instability in the region has also led herders to seek new areas to avoid conflict and theft of their cattle.

The opening of mining concessions in Itombwe from 1930 to 1960 led to the establishment of a road network and a major immigration of people into the massif. By 1970, with the exception of the Twanzige concession in the north, all commercial mining operations had been abandoned and the road network of the region began to collapse. At present, many former mines and their associated settlements and roads are covered by secondary forest and dense herbaceous undergrowth, colonized in some cases by gorillas and other wildlife. Small-scale gold panning continues at scattered locations throughout Itombwe. Most sites we visited were worked by fewer than 10 miners, and forest clearing and stream degradation were minor in most cases. A number of these mining camps served as a base for hunters, however, and the major impact of contemporary mining activities, especially in remote areas, is the reduction of local wildlife populations by market hunters.

Pit-sawing was recorded only in the SanjeMutambala Forest (sector F). Hand-sawn planks were formerly transported from this area by vehicle. Currently, they are carried on foot down the escarpment to local markets along Lake Tanganyika. According to informants, lack of transport has reduced rates of exploitation. However, we have no information to determine whether current levels of timber extraction are sustainable. Pit-sawing contributed to the forest degradation recorded at the bird survey sites of Kilumbi and Kabembwe.

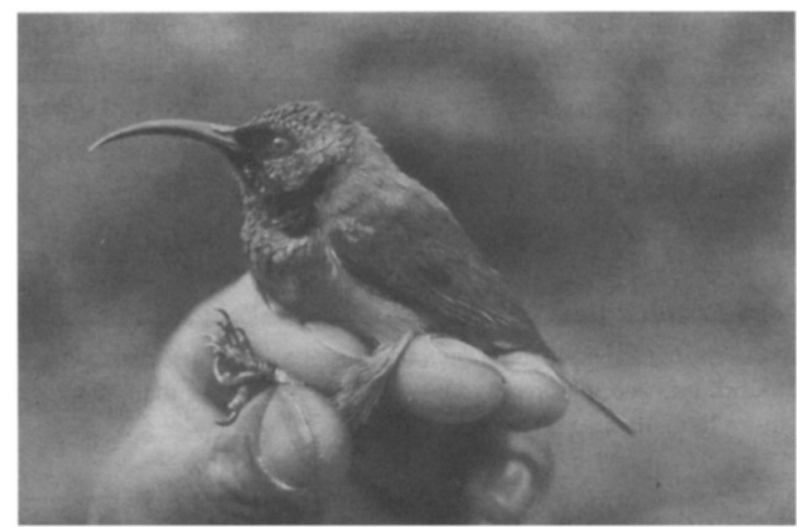

Plate 5 Blue-headed sunbird Nectarinia alinae, an Albertine Rift endemic species (C) Tom Butynski).

\section{Socio-economic surveys and conservation assessments}

Formal meetings were held with three state administrators resident in Itombwe and six traditional authorities (mwami) having customary jurisdiction over land allocation. In addition, we established contacts with traditional representatives of a number of the Bembe clans of the region, and with leaders of several local development-oriented non-governmental organizations (NGOs). Most of the individuals contacted cited the lack of roads, markets, schools and health care as the most important problems they faced. Traditional authorities in sectors $\mathrm{A}$ and $\mathrm{B}$ also cited excessive hunting pressure as a negative factor influencing their area. None of the authorities contacted had made any attempt to control deforestation in their areas, and only one local chief in the Kitibingi area (sector B) reported attempting to manage hunting. This individual had taken the exceptional initiative of forbidding market hunters from outside his area to enter forest under his control. We were unable to verify the effectiveness of this intervention.

Over half the local villagers contacted during the survey expressed ignorance of the protected status of gorillas. The availability and use of firearms was the single most important threat to gorillas. We were shown gorilla skulls and skins in 10 villages, and villagers reported having killed gorillas at an additional eight sites. Most of these animals were killed by hunters armed with shotguns. It was reported that at four sites gorillas had been killed within the preceding 12 months. The potential danger, real or imagined, that gorillas living in the vicinity of villages posed to humans was the most frequently cited reason for killing 


\begin{tabular}{llllll}
\hline Sector & Mining* & Hunting* $^{*}$ & Agriculture $^{*}$ & Grazing* $^{*}$ & Pit-sawing* $^{*}$ \\
\hline A & None found & ++ & + & None found & None found \\
B & + & ++ & ++ & ++ & None found \\
C & ++ & ++ & + & ++ & None found \\
D & + & ++ & ++ & + & None found \\
E & ++ & ++ & ++ & None found & None found \\
F & None found & + & ++ & ++ & + \\
\hline
\end{tabular}

Table 5 Observations of economic activities that have an impact on fauna and flora of the Itombwe Massif, Democratic Republic of Congo (1996); survey sectors are identified in Table 1 and Fig. 2

* Levels of activity based on observations on transects and reconnaissance walks: none found, no observations made; + , infrequent, fewer than 10 sites observed; ++ , frequent, more than 10 sites observed.

them. It was not clear from the interviews if levels of gorilla hunting in the vicinity of villages had increased in recent years. One gorilla and one chimpanzee caught in wire snares were encountered by survey teams. Snare captures of gorillas were also reported in villages in sectors $A$ and $B$; however, fewer were reported to have been killed in this way than with firearms.

Most local authorities and farmers who were interviewed acknowledged that the loss of forest and wildlife was not desirable. These same individuals, however, feared the creation of a national park in their area. Although many acknowledged that the locations of their villages and gardens had often changed in the past, most of them cited forced relocation of settlements as the principal potential negative impact of a park. Many individuals could accept the principle that hunting should be controlled. Indeed, some mentioned that the abandonment of traditional hunting sềasons (poona) was one reason why wildlife populations were currently over-exploited. None of the individuals interviewed was well informed about the biological diversity of Itombwe or the need for its conservation.

\section{Discussion}

The results of this survey, the first comprehensive assessment of the biological status of the Itombwe Massif in over 30 years, revealed that while significant areas of natural habitats remain in the region, these areas, along with their fauna and flora, are highly vulnerable to further degradation and loss. The turmoil of recent civil unrest, complicated by population growth, crop diseases and the poverty of the region, have left the future of the massif's natural habitats highly uncertain. $\mathrm{Hu}$ man activities have the most severe effects in areas to the north of the Elila River. Large stands of bamboo and montane forest have been almost completely converted to pasture. At least five of the 17 populations of gorillas identified by Emlen \& Schaller (1960) have disappeared over the last 38 years. Gorillas and chimpanzees are being killed or maimed by shotguns and snares in all areas. Market hunting threatens remaining wildlife populations over the entire region. The need for biological conservation in the Itombwe Massif could not be more urgent or compelling.

\section{Biodiversity surveys and conservation priorities}

Conservation planning in Itombwe must start with a knowledge of the distribution and status of the fauna and flora. With the possible exception of the region's birds, however, most of the fauna, and essentially its entire flora, are not adequately known. Preliminary studies suggest that amphibian diversity and endemism are likely to be high (Laurent, 1964). The smallmammal fauna also contains a number of endemic species (Kingdon, 1990, 1997; Nicoll \& Rathbun, 1990). This survey recorded a diversity of Impatiens, Begoniaceae and epiphytic orchids, but no systematic collections were made. While an inventory of these and other taxa are clearly needed, conservation action cannot wait until a full knowledge of the region's biota is in hand.

We present an assessment of Albertine Rift endemic birds and gorillas as a basis for conservation recommendations for the massif. These recommendations are presented with the knowledge that additional information and studies of other taxa may lead to modifications. However, both the Albertine Rift endemic birds and gorillas are dependent upon forest habitats. Thus, conservation of these species will also undoubtedly benefit other less well-known forest taxa.

The high species richness of forest birds, including the highest total of Albertine Rift montane endemics of any of the remaining Rift forests, has been cited as evidence for the occurrence in Itombwe of forest refugia during periods of climatic desiccation (Diamond \& Hamilton, 1980; Hamilton, 1981, 1982, 1988; DowsettLemaire \& Dowsett, 1990). The location of the massif at the forest savannah ecotone today, however, suggests that forest coverage in the region may actually have undergone significant reductions and insularization in the past. This may be one reason for the disjunct distribution of gorillas and the marked differences in 
the composition of bird faunas at different locations. Within the survey region, several conspicuous Albertine Rift endemics recorded at sites west of the central savannah plateau were apparently absent from otherwise similar forest habitats on the Lake Tanganyika escarpment east of the plateau (Table 3). A number of the other Albertine Rift endemics known to exist in the massif, including the Ruwenzori turaco Musophaga johnstoni, African green broadbill Pseudocalyptomena graueri and Rockefeller's sunbird Nectarinia rockefelleri, were not recorded at any of the bird survey locations, despite diligent searches in a variety of forested habitats. These results indicate that for endemic forest birds, the protection of just one or two areas will not assure the conservation of more than a portion of the species known to occur in the massif.

The prognosis for the apparently relict populations of gorillas best exemplifies why conservation in Itombwe will require the protection of a network of sites. Whether or not the gorillas were formerly more extensively linked, their current restriction in isolated, discrete populations decreases the likelihood that any single population is viable. Thus, conservation efforts should aim at ensuring the survival of as many populations as possible and the maintenance of potential corridors of forest habitat between them (Hall et al., 1998a).

While gorillas and Albertine Rift endemic birds are dependent upon forest habitats, they show marked differences in their tolerance of, or even preference for, areas that have been modified by humans. Mist-net captures of endemic understorey birds were lowest at the most degraded of the six sites sampled, although one Albertine Rift endemic, the Congo bay owl, was captured in a forest-grazed grassland ecotone in sector F (Butynski et al., 1997).

In contrast to Albertine Rift endemic birds, gorillas favoured broken, even degraded, areas within forest. Over half of the high-density gorilla zones were in fallow gardens and young secondary growth near villages or abandoned mining sites. The continued creation of small temporary clearings by shifting cultivators within forest may be essential for the continued occupation of some areas by gorillas.

The relationship between gorillas and humans in Itombwe must be monitored closely because evolving agricultural practices and the conversion of forests to cattle pastures may lead to the permanent loss of gallery and bamboo areas now occupied by gorillas. Even when not compromised by habitat loss, the survival of gorillas is threatened by human-induced mortality near villages.

We submit three priority recommendations for the conservation of the biodiversity of the Itombwe Massif.
1 Maintain areas of unoccupied and lightly degraded forest in all sectors of the massif, with the highest priority given to protection of the 10 identified gorilla areas.

2 Maintain the mosaic of both undisturbed and lightly disturbed environments across a range of altitudes and ecotones in the massif to ensure the conservation of the full range of Itombwe's biota.

3 Special protective measures should be established in high-density gorilla zones, including a total ban on hunting.

\section{Integrating local populations in conservation}

The first proposal for protection of Itombwe was Prigogine's (1985) call for a 7000-sq-km conservation area to include most of the massif and adjoining areas. More recently, Wilson \& Catsis (1990) and Doumenge (1998) recognized that this could not be realized, and probably would not be useful, because large areas have suffered degradation. Rather than one area with a single conservation status, a zoned landscape would be more appropriate, with options for differing management and control across a gradient of human use. Protected habitat islands, in a landscape in which deforestation and exploitation of the fauna are controlled, probably offer the best option for conservation of the massif's biodiversity.

Wilson \& Catsis (1990) and Schliter \& Doumenge (1993) emphasized the need to develop a conservation agenda in collaboration with local communities. Neither the traditional authorities of Itombwe nor local community organizations (NGOs) currently recognize biodiversity conservation, particularly of endemic species, as a priority. Given the immediate need for conservation in Itombwe, the most effective strategy may be to negotiate an end to the most destructive human activities in critical areas, ensuring that exploitation of fauna and flora are at sustainable levels. For gorillas, protective measures must be applied immediately if losses of additional populations are to be avoided. The same holds true for the region's remnant elephant populations.

\section{Political instability and conservation strategies}

The African Great Lakes region, which includes the Itombwe Massif, is one of the most densely populated and economically undeveloped areas on the continent. Current civil unrest in the region represents a potentially major transition in political authority, with an uncertain outcome (Homer-Dixon et al., 1993). Protection of critical habitats, and vulnerable fauna and flora, should be initiated, even if the political future of the region is unresolved. Under current circumstances, the 
support of local authorities for conservation activities is essential, but state-level designation of a protected area in the region should be sought also. In many areas of Itombwe, traditional chiefs hold power over allocation of land rights. Contractual agreements with these individuals may provide a basis for protection of some sites. Working in collaboration with traditional authorities may be the only way at present to initiate protective measures, which, while potentially acceptable in the long term, offer few solutions to the immediate problems of an impoverished and demographically unstable population (Noss, 1997). Any conservation interventions must be monitored and evaluated continuously because political instability within the region will probably necessitate frequent negotiations of agreements and positions. A public relations and education programme aimed at informing local populations of the need for conservation has created support for the protection of Kahuzi-Biega National Park, located to the north of Itombwe (Birhashirwa, 1996). Similar programmes should be undertaken in Itombwe.

In Congo over the last few years, experiences in protecting national parks and reserves during periods of insecurity have shown that the presence of a dedicated local staff, working with a minimum of ensured support and with an ability to engage with national and international collaborators, can both prevent some disasters and take advantage of unforeseen opportunities to enhance protection (Hart et al., 1996; Hart \& Hart, 1997). Developing and supporting this capacity in Itombwe is a priority. Thirty years of isolation have clearly not served to protect Itombwe's flora and fauna. Engagement of the conservation community in the protection of the massif is necessary now if the remarkable biodiversity of this unique region is to be preserved.

\section{Acknowledgements}

The Itombwe Survey constituted the penultimate phase of the global survey of the Grauer's subspecies of the eastern gorilla (1993-96) undertaken by the ICCN and the WCS. Major financial support for this study was provided by WCS, with contributions from the Robert Wood Johnson Foundation and the Disney Wildlife Conservation Award. The participation of T. Butynski was supported by Zoo Atlanta, Berggorilla und Regenwald Direkthilfe and the Disney Wildlife Conservation Award. We acknowledge also the assistance of Zoo Atlanta in producing the maps and figures that accompany this article. We would like to thank Stanislas Bakinahe, ICCN Provincial Director for South Kivu, for assistance in obtaining civil and military authorizations.
Jefferson Hall, project leader for the Grauer's gorilla survey, provided the impetus for this study and participated in planning and staff training. We are particularly grateful for his assistance in analyzing data and interpreting gorilla nest counts. Guy Debonnet and Rene Beyers generously provided maps of Itombwe and field notes on Itombwe birds. Andrew Plumptre and Terese Hart edited earlier drafts of this paper. Finally, our sincere thanks to our field assistants, porters and guides for their courageous and dedicated service.

\section{References}

Barnes, R.F.W. \& Jensen, K.L. (1987) How to count elephants in forests. African Elephant and Rhino Specialist Group, Technical Bulletin, 1, 1-6.

Barnes, R.F.W., Blom, A., Alers, M. \& Barnes, K.L. (1995) An estimate of the number of forest elephants in Gabon. Journal of Tropical Ecology, 11, 27-37.

Birhashirwa, N.R. (1996) Rapport de mission de sensibilisation au Project WCS-IZCN/Programme-Itombwe. Unpublished report to IZCN, Bukavu.

Butynski, T.M, Upoki, A., Bagurubumwe, N. \& Hart, J.A. (1997) Rediscovery of the Congo bay (Itombwe) owl Phodilus prigoginei. Bulletin of the African Bird Club, 4, 32-35.

Collar, N.J. \& Stuart, S.N. (1988) Key Forests for Threatened Birds in Africa. ICBP Monograph No. 3, International Council for Bird Preservation, Cambridge, UK.

Diamond, A.W. \& Hamilton, A.C. (1980) The distribution of forest passerine birds and Quaternary climatic change in tropical Africa. Journal of Zoology, London, 191, 379-402.

Doumenge, C. (1998) Forest diversity, distribution and dynamique in the Itombwe Mountains, South-Kivu, Congo Democratic Republic. Mountain Research and Development, 18, 249-264.

Dowsett-Lemaire, F. \& Dowsett, R.J. (1990) Zoogeography and taxonomic relationships of the forest birds of the Albertine Rift afromontane region. Turaco Research Report, 3, 87-109.

Dowsett, R.J. \& Forbes-Watson, A.D. (1993) Checklist of the Birds of the Afrotropical and Malagasy Regions. Tauraco Press, Liège.

Emlen, J.T. \& Schaller, G.B. (1960) Distribution and status of the mountain gorilla (Gorilla gorilla beringei) -1959 . Zoologica, 45, 309-323.

Hall, J.S. \& Wathaut, W.M. (1992) A Preliminary Survey of the Eastern Lowland Gorilla. Unpublished report to Wildlife Conservation Society, New York.

Hall, J., Inogwabini, B.I., Williamson, E., Omari, I., Sikubwabo, C. \& White, L. (1997) A survey of elephants (Loxodonta africana) in the Kahuzi-Biega National Park lowland sector and adjacent forest in eastern Zaire. African Journal of Ecology, 35, 213-223.

Hall, J., Saltonstall, K., Inogwabini, B.I. \& Omari, I. (1998a) Distribution, abundance and conservation status of Grauer's gorilla (Gorilla gorilla graueri). Oryx, 32, 122-130. 
Hall, J., White, L., Inogwabini, B.I., Omari, I., SimonsMorland, H., Williamson, E. et al. (1998b) Survey of Grauer's gorillas (Gorilla gorilla graueri) and chimpanzees (Pan troglodytes schweinfurthii) in the Kahuzi-Biega National Park lowland sector and adjacent forest in eastern Zaire. International Journal of Primatology, 19, 207-235.

Hamilton, A.C. (1981) The Quaternary history of African forests: its relevance to conservation. African Journal of Ecology, 19, 1-6.

Hamilton, A.C. (1982) Environmental History of East Africa: A Study of the Quaternary. Academic Press, London.

Hamilton, A.C. (1988) Guenon evolution and forest history. In A Primate Radiation: Evolutionary Biology of the African Guenons (eds A. Gautier-Hion, F. Bourlière, J-P. Gautier-Hion and J. Kingdon), pp. 13-34. Cambridge University Press, Cambridge.

Hart, J. \& Hall, J. (1996) Status of eastern Zaire's forest parks and reserves. Conservation Biology, 10(2), 316-327.

Hart, T. \& Hart, J. (1997) Conservation and conflict in Central Africa. Conservation Biology, 11(2), 308-309.

Hart, T., Hart, J. \& Hall, J. (1996) Conservation in the declining nation state: the case of eastern Zaire. Conservation Biology, 10(2), 685-686.

Homer-Dixon, T., Boutewell, J. \& Rathjens, G. (1993) Environmental change and violent conflict. Scientific American, February, 38-45.

Kingdon, J. (1990) Island Africa. Collins, London.

Kingdon, J. (1997) The Kingdon Field Guide to African Mammals. Academic Press, London.

Laake, J.L., Buckland, S.T., Anderson, D.R. \& Burnham, K.P. (1994) Distance Users Guide. V2.1. Colorado Cooperative Fish and Wildlife Research Unit, Colorado State University, Fort Collins.

Laurent, R.F. (1964) Adaptive modifications in frogs in an isolated highland fauna in Central Africa. Evolution, 18, 458-467.

Matschie, P. (1914) Neue Affen aus Mittelafrika. Sitzungs-berichte der Gesellschaft naturforschender Freunde $z u$ Berlin, 323-349.

Nicoll, M.E. \& Rathbun, G.B. (1990) African Insectivores and Elephant-Shrews. An Action Plan for their Conservation. IUCN, Gland, Switzerland.

Noss, A. (1997) Challenges of nature conservation with community development in central African forests. Oryx, 31, 180-188.

Omari, I. (1997) Les Résultats de la Mission IZCN/WCS Itombwe: Rapport Preliminaire. Unpublished report to IZCN/WCS, Kinshasa.

Prigogine, A. (1971) Les Oiseaux de l'Itombwe et de son Hinterland. Vol. 1. Musée Royal de l'Afrique Centrale. Annales Série 8, Sciences zoologiques, 185.

Prigogine, A. (1978) Les Oiseaux de l'Itombwe et de son Hinterland. Vol. 2. Musée Royal de l'Afrique Centrale. Annales Série 8, Sciences zoologiques, 223.

Prigogine, A. (1984) Les Oiseaux de l'Itombwe et de son Hinterland. Vol. 3. Musée Royal de l'Afrique Centrale, Annales Série 8, Sciences zoologiques, 243.

Prigogine, A. (1985) Conservation of the avifauna of the forests of the Albertine Rift. In Conservation of Tropical Forest Birds (eds A. W. Diamond and T. E. Lovejoy), pp.
275-295. ICBP Technical Publication No. 4, International Council for Bird Preservation, Cambridge, UK.

Schliter, C. \& Doumenge, C. (1993) Programme Itombwe: Rapport de Mission 19 juillet au 19 août 1993. Unpublished report to IZCN/UICN, Bukavu.

Sikubwabo, C.K. (1993) Rapport d'une Mission d'enquête Faune-chasse: Programme Itombwe. Unpublished report to IZCN/UICN, Bukavu.

Stattersfield, A.J., Crosby, M.J., Long, A.J. \& Wege, D.C. (1998) Endemic Bird Areas of the World: Priorities for Biodiversity Conservation. Bird Conservation Series, No. 7 . BirdLife International, Cambridge, UK.

Stubbs, D. (1988) The Itombwe Mountains, Eastern Zaire: A Feasibility Assessment for Establishing a New African Forest Conservation Project. Unpublished report to Fauna and Flora Preservation Society, London.

Tutin, C., Parnell, R., White, L. \& Fernandez, M. (1995) Nest building by lowland gorillas in the Lopé Reserve, Gabon: environmental influences and implications for censusing. International Journal of Primatology, 16, 55-76.

Wilson, J.R. \& Catsis, M.C. (1990) A Preliminary survey of the forests of the Ttombwe' Mountains and the Kahuzi-Biega National Park Extension, East Zaire, July-Sept 1989. Unpublished report to WWF/FFPS/IZCN, Project 3902, Kinshasa.

Wilson, D.E. \& Reeder, D.M. (1993) Mammal Species of the World. A Taxonomic and Geographic Reference. Smithsonian Institution Press, Washington and London.

\section{Biographical sketches}

Omari Ilambu is Research Associate with the Congolese Institute of Nature Conservation, and Senior National Staff with the WCS's Democratic Republic of Congo Programme. His previous work includes inventories of great apes and other large mammals in eastern Congo protected areas.

John A. Hart is Senior Scientist with the WCS. His fieldwork in Congo has focused on the ecology, behaviour and conservation of rain-forest fauna, and has included surveys of Congo peacock, radio-telemetry studies of okapi and other forest ungulates, and studies of the impact of human hunting on ungulate populations. He is currently developing protocols for faunal surveys in Congo's post-war protected areas.

Thomas Butynski is the Senior Conservation Biologist for Zoo Atlanta's Africa Biodiversity Conservation Programme, Vice-Chair of the African Section of the IUCN/ SSC Primate Specialist Group, and Senior Editor of African Primates. His fieldwork in Congo has focused on the conservation of Afro-montane forests, particularly their primate and bird faunas. 
Appendix 1: Survey locations in the Itombwe Massif, Democratic Republic of Congo (1996); numbered locations refer to Fig. 2

\begin{tabular}{|c|c|c|c|c|c|}
\hline Map & Location & Latitude $^{*}(\mathrm{~S})$ & Longitude* $(\mathrm{E})$ & Altitudet (m) & Site \\
\hline 1 & Nundu & $3^{\circ} 48.9^{\prime}$ & $29^{\circ} 05.9^{\prime}$ & 825 & Village \\
\hline 2 & Kabembwe & $3^{\circ} 52.6^{\prime}$ & $29^{\circ} 00.3^{\prime}$ & 1850 & Village \\
\hline 3 & Kilumbi & $3^{\circ} 52.2^{\prime}$ & $28^{\circ} 56.1^{\prime}$ & 1900 & Village \\
\hline 4 & Kanguli & $3^{\circ} 52.6^{\prime}$ & $28^{\circ} 52.5^{\prime}$ & 1600 & Village \\
\hline 5 & Tulambo & $3^{\circ} 42.5^{\prime}$ & $28^{\circ} 41.1^{\prime}$ & 2000 & Village \\
\hline 6 & Tbachilo & $3^{\circ} 37.8^{\prime}$ & $28^{\circ} 28.4^{\prime}$ & 1550 & Village \\
\hline 7 & West Ibachilo & - & - & 1850 & Forest camp \\
\hline 8 & Mt Kasondjo & $3^{\circ} 32.0^{\prime}$ & $28^{\circ} 34.4^{\prime}$ & 2000 & Near summit \\
\hline 9 & Elila River & - & - & - & Camp \\
\hline 10 & Mt Lundjei & $3^{\circ} 29.9^{\prime}$ & $28^{\circ} 44.1^{\prime}$ & 2600 & Summit \\
\hline 11 & Kitibingi & $3^{\circ} 30.0^{\prime}$ & $28^{\circ} 29.2^{\prime}$ & 1270 & Village \\
\hline 12 & Ngomiano & - & - & - & Village \\
\hline 13 & Kabelukwa & $3^{\circ} 31.1^{\prime}$ & $28^{\circ} 25.3^{\prime}$ & 1170 & Village \\
\hline 14 & Mt lbenga & $3^{\circ} 27.7^{\prime}$ & $28^{\circ} 418^{\prime}$ & 1970 & Abandoned mine \\
\hline 15 & South Kiandjo & $3^{\circ} 24.7^{\prime}$ & $28^{\circ} 39.4^{\prime}$ & 1850 & Transect location \\
\hline 16 & Kapanga & $3^{\circ} 28.3^{\prime}$ & $28^{\circ} 40.2^{\prime}$ & 1850 & Abandoned mining centre \\
\hline 17 & Lueno & - & - & - & Village \\
\hline 18 & Milanga & $3^{\circ} 26.4^{\prime}$ & $28^{\circ} 25.4^{\prime}$ & - & Village \\
\hline 19 & Miki & $3^{\circ} 22.0^{\prime}$ & $28^{\circ} 41.0^{\prime}$ & 2000 & Village centre \\
\hline 20 & Mt Kipapa & - & - & - & Camp \\
\hline 21 & Mulamboze & - & - & - & Village and bush-meat market \\
\hline 22 & Mukunguzi & - & - & - & Village \\
\hline 23 & Mt Ngusa & $3^{\circ} 18.4^{\prime}$ & $28^{\circ} 41.9^{\prime}$ & 2600 & Near summit \\
\hline 24 & Kakanga & - & - & - & Village \\
\hline 25 & Nzombe & - & - & - & Abandoned mining centre \\
\hline 26 & Mwenga & $3^{\circ} 02.4^{\prime}$ & $28^{\circ} 25.9^{\prime}$ & 1490 & Village, mining centre and market \\
\hline
\end{tabular}

* Geographic co-ordinates determined by GPS.

+ Altitudes determined by altimeter and GPS.

-, GPS and altimeter readings not available.

Appendix 2: Mammals recorded in Itombwe, Democratic Republic of Congo, 1996*

\begin{tabular}{|c|c|c|c|c|c|c|c|c|}
\hline \multirow[b]{2}{*}{ English name } & \multirow[b]{2}{*}{ Scientific name } & \multicolumn{7}{|c|}{ Sectort } \\
\hline & & $\mathrm{A}$ & B & C & $\mathrm{D}$ & $\mathbf{E}$ & $\mathbf{F}$ & Record $\ddagger$ \\
\hline \multicolumn{9}{|l|}{ Bats } \\
\hline Hammer-headed fruit bat & Hypsignathus monstrosus & + & + & - & - & - & - & $\mathrm{O}$ \\
\hline \multicolumn{9}{|l|}{ Insectivores } \\
\hline Otter shrew & Potamogale velox & + & - & - & - & - & + & $S$ \\
\hline \multicolumn{9}{|l|}{ Primates } \\
\hline Potto & Perodicticus potto & + & - & - & - & - & - & $\mathrm{S}$ \\
\hline Greater galago & Otolemur crassicaudatus & - & - & - & - & - & + & $\mathrm{O}, \mathrm{R}$ \\
\hline Spectacled galago & Galago matschiei & - & - & - & - & - & + & $\mathrm{S}$ \\
\hline Demidoff's dwarf galago & Galagoides demidoff & - & - & - & - & - & + & $\mathrm{R}$ \\
\hline Thomas's dwarf galago & Galagoides thomasi & - & - & - & - & - & + & $\mathbf{R}$ \\
\hline Olive baboon & Papio anubis & - & - & - & - & - & + & $\mathrm{S}$ \\
\hline Gorilla & Gorilla gorilla & + & + & + & + & + & + & $\mathrm{S}, \mathrm{O}$ \\
\hline Chimpanzee & Pan troglodytes & + & + & + & + & + & + & $\mathrm{S}, \mathrm{O}$ \\
\hline Red colobus & Piliocolobus oustaleti (foai) & + & - & + & + & - & - & $\mathrm{O}$ \\
\hline Angolan colobus & Colobus angolensis & - & + & - & - & + & + & $\mathrm{S}, \mathrm{O}$ \\
\hline L'Hoest's monkey & Cercopithecus lhoesti & + & + & - & - & - & - & $\mathrm{S}, \mathrm{O}$ \\
\hline Blue monkey & Cercopithecus mitis & + & + & - & + & - & + & $\mathrm{O}$ \\
\hline Red-tailed monkey & Cercopithecus ascanius & + & + & + & - & + & + & $\mathrm{S}, \mathrm{O}$ \\
\hline Dent's monkey & Cercopithecus denti & + & - & + & - & + & - & $\mathrm{S}, \mathrm{O}$ \\
\hline Grey-cheeked mangabey & Lophocebus albigena & - & - & + & + & - & - & $\mathrm{O}$ \\
\hline
\end{tabular}


Appendix 2 (continued)

\begin{tabular}{|c|c|c|c|c|c|c|c|c|}
\hline \multirow[b]{2}{*}{ English name } & \multirow[b]{2}{*}{ Scientific name } & \multicolumn{7}{|c|}{ Sectort } \\
\hline & & $\mathrm{A}$ & B & $\mathrm{C}$ & $\mathrm{D}$ & $\mathrm{E}$ & $\mathrm{F}$ & Record $\neq$ \\
\hline \multicolumn{9}{|l|}{ Carnivores } \\
\hline White-naped weasel & Poecilogale albinucha & - & + & - & - & - & + & $S$ \\
\hline Ratal & Mellivora capensis & + & + & - & - & - & + & $S$ \\
\hline Spotted-neck otter & Lutra maculicollis & + & + & - & - & - & + & $\mathrm{S}$ \\
\hline Alexander's cusimanse & Crossarchus alexandri & - & + & + & - & - & - & $\mathrm{O}$ \\
\hline Marsh mongoose & Atilax paludinosus & - & + & - & - & - & - & $\mathrm{O}$ \\
\hline Blotched genet & Genetta tigrina & - & + & - & - & - & + & $\mathrm{S}$ \\
\hline Servaline genet & Genetta servalina & - & + & - & - & - & - & S \\
\hline Common genet & Genetta genetta & - & - & - & - & - & + & S \\
\hline Linsang & Poiana richardsonii & - & + & + & - & - & + & $S$ \\
\hline African civet & Civettictis civetta & + & - & - & - & - & - & $\mathrm{O}$ \\
\hline African palm civet & Nandinia binotata & - & - & - & - & - & + & $S$ \\
\hline Leopard & Panthera pardus & - & - & + & - & - & - & $\mathrm{O}$ \\
\hline Serval & Leptailurus serval & - & + & - & - & - & + & $S$ \\
\hline \multicolumn{9}{|l|}{ Elephant } \\
\hline Elephant & Loxodonta africana & + & + & + & + & - & - & $\mathrm{O}$ \\
\hline \multicolumn{9}{|l|}{ Hyrax } \\
\hline Tree hyrax & Dendrohyrax sp. & + & - & + & - & - & - & $\mathrm{S}, \mathrm{O}$ \\
\hline \multicolumn{9}{|l|}{ Pangolins } \\
\hline Tree pangolin & Manis tricuspis & + & + & + & - & - & - & $S$ \\
\hline Long-tailed pangolin & Manis tetradactyla & - & + & - & - & - & - & S \\
\hline Giant pangolin & Manis gigantea & + & - & - & - & - & - & 0 \\
\hline \multicolumn{9}{|l|}{ Aardvark } \\
\hline Aardvark & Orycteropus afer & + & + & - & - & - & - & $\mathrm{O}$ \\
\hline \multicolumn{9}{|l|}{ Rodents } \\
\hline Crested porcupine & Hystrix cristata & - & + & - & - & - & - & $\mathrm{O}$ \\
\hline Brush-tailed porcupine & Atherurus africanus & + & + & - & - & - & - & $\mathrm{S}$ \\
\hline Cane rat & Thryonomys sp. & + & + & + & - & - & - & $\mathrm{O}$ \\
\hline Giant pouched rat & Cricetomys emini & + & - & - & - & - & - & $S$ \\
\hline Giant squirrel & Protoxerus stangeri & - & + & - & - & - & - & $S$ \\
\hline Carruther's mountain squirrel & Funisciurus carruthersi & - & + & - & - & - & + & $\mathrm{S}, \mathrm{O}$ \\
\hline Boehm's squirrel & Paraxerus boehmi & + & + & - & - & - & - & $\mathrm{O}$ \\
\hline Derby's anomalure & Anomalurus derbianus & - & - & - & - & - & + & $\mathrm{S}, \mathrm{O}$ \\
\hline \multicolumn{9}{|l|}{ Ungulates } \\
\hline Red river hog & Potamochoerus porcus & + & + & + & - & + & - & $\mathrm{O}$ \\
\hline Giant hog & Hylochoerus meinertzhageni & - & + & - & - & - & - & S \\
\hline Water chevrotain & Hyemoschus aquaticus & + & + & - & - & - & - & $\mathrm{O}$ \\
\hline Buffalo & Syncerus caffer & - & + & + & + & + & - & $\mathrm{O}$ \\
\hline Bushbuck & Tragelaphus scriptus & - & + & - & - & - & + & $S$ \\
\hline Sitatunga & Tragelaphus spekii & + & + & + & - & - & - & $S$ \\
\hline Yellow-backed duiker & Cephalophus sylvicultor & + & + & + & - & - & - & $\mathrm{S}, \mathrm{O}$ \\
\hline Peter's duiker & Cephalophus callipygus & + & + & - & + & + & - & $\mathrm{S}, \mathrm{O}$ \\
\hline Black-fronted duiker & Cephalophus nigrifrons & + & + & + & + & + & + & $\mathrm{S}, \mathrm{O}$ \\
\hline Bay duiker & Cephalophus dorsalis & + & + & - & - & - & - & $\mathrm{O}$ \\
\hline Blue duiker & Cephalophus monticola & + & + & + & + & + & - & $\mathrm{S}, \mathrm{O}$ \\
\hline Bate's pygmy antelope & Neotragus batesi & + & + & - & - & - & - & $\mathrm{S}$ \\
\hline
\end{tabular}

* Species names mainly follow Wilson \& Reeder (1993).

+ For locations of sectors refer to Fig. 2.

$\ddagger O$, observation of animal or sign; $R$, call recorded; $S$, specimen collected or photographed. 
Appendix 3: Bird species found in the Itombwe Massif, Democratic Republic of Congo, during the 1996 survey that were not recorded by Prigogine $(1971,1978,1984)$ for the region

\begin{tabular}{lll}
\hline Area & Habitat and altitude $(\mathrm{m})$ & Species* \\
\hline Lake Tanganyika escarpment & Savannah and agriculture & Micronisus gabar \\
& $900-1750$ & Numida meleagris \\
Centropus superciliosus & Polemaetus bellicosus \\
& & Halcyon chelicuti \\
Lake Tanganyika escarpment & Merops pusillus \\
& Miombo woodland & Caprimulgus nigriscapularis \\
& $900-1500$ & Anthus lineiventris \\
& & Eremomela scotops \\
Plateau and south-west massif & Cercomela familiaris \\
& & Pytilia afra \\
& Montane forest and savannah & Polyboroides typus \\
& $1700-2600$ & Hieraetus dubius \\
& & Bostrychia olivacea \\
& & Aquila wahlbergi \\
& & Musophaga rossae \\
& & Bucorvus cafer \\
& Caprimulgus natalensis
\end{tabular}

* Species names follow Dowsett \& Forbes-Watson (1993). 